\title{
Overexpression of the Epidermal Growth Factor Receptor Confers Migratory Properties to Nonmigratory Postnatal Neural Progenitors
}

\author{
Adan Aguirre, ${ }^{1}$ Tilat A. Rizvi, ${ }^{2}$ Nancy Ratner, ${ }^{2}$ and Vittorio Gallo ${ }^{1}$ \\ ${ }^{1}$ Center for Neuroscience Research, Children's Research Institute, Children's National Medical Center, Washington, DC 20010, and 2Division of \\ Experimental Hematology, Department of Pediatrics, Cincinnati Children's Hospital Research Foundation, University of Cincinnati College of Medicine, \\ Cincinnati, Ohio 45229
}

\begin{abstract}
Approaches to successful cell transplantation therapies for the injured brain involve selecting the appropriate neural progenitor type and optimizing the efficiency of the cell engraftment. Here we show that epidermal growth factor receptor (EGFR) expression enhances postnatal neural progenitor migration in vitro and in vivo. Migratory NG2-expressing $\left(\mathrm{NG} 2{ }^{+}\right)$progenitor cells of the postnatal subventricular zone (SVZ) express higher EGFR levels than nonmigratory, cortical NG2 ${ }^{+}$cells. The higher endogenous EGFR expression in SVZ $\mathrm{NG}^{+}$cells is causally related with their migratory potential in vitro as well as in vivo after cell engraftment. EGFR overexpression in cortical NG2 ${ }^{+}$cells by transient transfection converted these cells to a migratory phenotype in vitro and in vivo. Finally, cortical NG2 ${ }^{+}$ cells purified from a transgenic mouse in which the EGFR is overexpressed under the CNP promoter exhibited enhanced migratory capability. These findings reveal a new role for EGFR in the postnatal brain and open new avenues to optimize cell engraftment for brain repair.
\end{abstract}

Key words: CNP-EGFP mouse; cell transplantation; cell migration; rostral migratory stream; white matter; hippocampus; olfactory bulb

\section{Introduction}

The use of cell transplantation for brain repair depends on neural progenitors that retain their ability to proliferate, migrate, and differentiate to repopulate areas of lesions. A first step in designing cell repair strategies is to analyze the developmental properties of specific neural progenitor populations, to identify intrinsic mechanisms that could be exploited to promote cell regeneration by using endogenous or grafted cells.

The postnatal brain contains populations of progenitors that display different proliferative and migratory potentials. The most extensively characterized are those found in the subventricular zone (SVZ) (Doetsch et al., 1999, 2002) and in the dentate gyrus (Gage, 2000). One class of progenitors in these areas expresses the proteoglycan NG2. NG2 ${ }^{+}$cells are the most numerous progenitor population of the postnatal brain (Dawson et al., 2000) and

Received July 19, 2005; revised 0ct. 12, 2005; accepted 0ct. 16, 2005.

This work was supported by National Institutes of Health (NIH) Grants R01NS045702 (V.G.) and R01NS028840 (N.R.), by the Wadsworth Foundation (V.G.), by Department of Defense Grants DAMD-17-02-1-0679 (N.R.) and DAMD-17-01-1-075 (T.R.), and by NIH Mental Retardation Developmental Disabilities Research Center Grant P30HD40677. We are very grateful to Stacey Roundtree and Dr. L. J. Chew for breeding and maintenance of the CNP-EGFP mice. We thank Rebecca Grimm and Dr. J. Wu for breeding and genotyping the CNP-hEGFR mice. We thank Kelly Monk for real-time PCR. We thank W. King and Teresa Hawley for assistance with FACS sorting. We thank Dr. W. J. Gullick (Hammersmith Hospital, London, UK) for the kind gift of the constitutively active human EGFR plasmid (phEGFRviii). We are particularly grateful to Drs. Marla Luskin and Shibeshih Belachew for stimulating discussion. We thank Drs. S. Belachew, L.-J. Chew, T. Haydar, B. Jablonska, and D. Panchision for critical comments on this manuscript.

Correspondence should be addressed to Dr. Vittorio Gallo, Center for Neuroscience Research, Children's Research Institute, Children's National Medical Center, Washington, DC 20010-2970. E-mail: vgallo@cnmcresearch.org. DOI:10.1523/JNEUROSCI.2981-05.2005

Copyright $\odot 2005$ Society for Neuroscience ～0270-6474/05/2511092-15\$15.00/0 can be either highly proliferative and migratory, such as in the SVZ, or slowly dividing and nonmigratory, such as in the cerebral cortex and olfactory bulb (OB) (Belachew et al., 2002; Aguirre and Gallo, 2004; Aguirre et al., 2004). We have demonstrated previously that $\mathrm{SVZ} \mathrm{NG} 2{ }^{+}$cells isochronically transplanted into the lateral ventricle (LV) proliferate and migrate caudally to the hippocampus and subcortical white matter (SCWM) and to the $\mathrm{OB}$ via the rostral migratory stream (RMS) (Aguirre and Gallo, 2004). Conversely, grafted cortical NG2 ${ }^{+}$cells neither proliferate nor migrate out of the LV (Aguirre and Gallo, 2004). These findings raise important questions about the intrinsic properties that render a progenitor cell proliferative and migratory and provide the opportunity to define signaling molecules that may promote proliferation and migration in quiescent neural progenitors.

Several molecular signals have been implicated in neuroblast tangential migration, including the following: (1) the polysialylated form of the neural cell-adhesion molecule, which confers a migratory phenotype to neuroblasts (Pencea and Luskin, 2003); (2) deleted in colorectal carcinoma and integrins, which mediate directional migration of neural precursors (Murase and Horwitz, 2002); (3) the soluble ligands Slit1 and Slit2, as guidance signals (Bagri et al., 2002), and (4) members of the receptor tyrosine kinase family (RTK), which includes the Eph family and their transmembrane-associated ephrin ligands (Conover et al., 2000) and members of the Erb RTK family, particularly Erb4 and its ligand neuregulin (Anton et al., 2004; Corfas et al., 2004; Flames et al., 2004). The Erb RTK family also includes the epidermal growth factor receptor (EGFR) (Erb1) and its ligand EGF, which 
play an important role in the proliferation and maintenance of embryonic and adult neural stem cells (Doetsch et al., 1999, 2002; Gage, 2000; Junier, 2000; Yarden and Sliwkowski, 2001). The EGFR is directly involved in the radial migration and maturation of neural precursors during embryonic cortical development (Burrows et al., 1997, 2000; Kornblum et al., 1997; Caric et al., 2001; Ciccolini et al., 2005), but its functional role in postnatal neural progenitor is not completely defined.

In the present study, we demonstrate that EGFR overexpression in nonmigratory cortical NG2 ${ }^{+}$cells induces these cells to migrate from the SVZ into the SCWM, the hippocampus, and the RMS/OB after grafting. Our results indicate that increasing EGFR expression in neural progenitor cells to enhance their migratory potential may help to develop new transplantation therapies by optimizing cell engraftment in different brain regions.

\section{Materials and Methods}

Transgenic mice. The CNP-enhanced green fluorescent protein (EGFP) and $\beta$-actin-GFP transgenic mice (Tg ActbGFP) (stock number 003772; The Jackson Laboratory, Bar Harbor, ME) have been described previously (Belachew et al., 2002; Yuan et al., 2002; Aguirre and Gallo, 2004). Details on the generation and characterization of the CNPase-hEGFR transgenic mice have been reported previously (Ling et al., 2005). Genotyping of these transgenic mice was performed by PCR (Ling et al., 2005). Transgenic mice were backcrossed more than four generations onto C57BL/6 mice. In two lines of CNPase-hEGFR mice, including the one used here, no obvious defects in brain oligodendrocytes were detected. For example, there was no change in width of the adult corpus callosum. Consistent with CNP driving expression in oligodendrocytes, robust hEGFR expression in total brain and spinal cord lysates from adult brain was detected previously by using monoclonal anti-human EGFR antibody to probe Western blots after immunoprecipitation with a polyclonal anti-EGFR antibody (Ling et al., 2005). In addition, hEGFR expression was detected in oligodendrocyte lineage cells of the white matter in both postnatal day 15 (P15) and adult CNPase-hEGFR mice (A. Aguirre and V. Gallo, unpublished observation). All animal procedures were performed according to the Institutional Animal Care and Use Committee of Children's National Medical Center and the National Institutes of Health guidelines.

Real-time PCR. Messenger RNA was extracted from postnatal day 8 whole brain and SVZ using the Micro-FastTrack kit for isolation of mRNA from small samples (Invitrogen, Carlsbad, CA). The mRNA was DNase treated (New England Biolabs, Ipswich, MA) according to the instructions of the manufacturer and purified with phenol chloroform. cDNA was generated as described previously (Ling et al., 2005), and duplicate samples lacking reverse transcriptase were conducted to control for genomic DNA contamination. Mouse glyceraldehyde-3phosphate dehydrogenase (GAPDH) primers (sense, 5' -ACCCAGAAGACTGTGGATGG; antisense, 5'-GGAGACAACCTGGTCCTCAG; expected product size, $300 \mathrm{bp}$ ) were included in each reaction as a positive control for cDNA. For quantitative real-time PCR experiments, cDNA was used (as generated above), as were primers for known EGFR ligands: amphiregulin, betacellulin EGF, epiregulin, heparin-binding EGF, and transforming growth factor $\alpha$ (TGF $\alpha$ ) (sequences available on request). Duplicate experiments with triplicate reactions were performed in an ABI Prism 7700 Sequence Detection System Cycler (Applied Biosystems, Foster City, CA) according to the instructions of the manufacturer. Briefly, $1 \mu \mathrm{l}$ of cDNA or water control was placed into a $50 \mu \mathrm{l}$ reaction volume containing $25 \mu \mathrm{l}$ of SYBR Green Master Mix ( $2 \times$ concentration; Applied Biosystems) and volumes of primers that ranged between 0.5 and $9 \mu \mathrm{l}$, depending on the optimal conditions for each primer set. The remaining volume comprised water. The thermal cycling conditions comprised an initial equilibration step at $60^{\circ} \mathrm{C}(2 \mathrm{~min})$, a denaturation step at $95^{\circ} \mathrm{C}(10 \mathrm{~min})$, followed by 40 cycles of $95^{\circ} \mathrm{C}(15 \mathrm{~s})$ and $60^{\circ} \mathrm{C}(1 \mathrm{~min})$. When applicable, cycle threshold $\left(\mathrm{C}_{\mathrm{t}}\right)$ values were obtained from the point during amplification at which the fluorescent intensity was in the geometric phase, as determined by PE Applied Bio- systems (Foster City, CA) analysis software. All PCR products were analyzed on a $2 \%$ agarose gel. When applicable, the $\Delta C_{t}$ values were determined for whole brain and SVZ, and relative ligand expression was calibrated to GAPDH expression (primers as above). Fold change of ligands in SVZ compared with whole brain were calculated using the established equation (K. Luvak, PE ABI Sequence Detector User Bulletin $2): 2^{-\Delta \Delta C t}$, where $C_{t}$ is the cycle number at the chosen amplification threshold, $\Delta \mathrm{C}_{\mathrm{t}}=\mathrm{C}_{\mathrm{t}(\text { ligand })}-\mathrm{C}_{\mathrm{t}(\mathrm{GAPDH})}$, and $\Delta \Delta \mathrm{C}_{\mathrm{t}}=\Delta \mathrm{C}_{\mathrm{t}(+/-)}-$ $\Delta \mathrm{C}_{\mathrm{t}(+/+)}$.

SVZ explants migration assays. P8 brains from CNP-EGFP mice were dissected out and transferred to ice-cold HBSS medium (Invitrogen). The brains were cut in $200 \mu \mathrm{m}$-thick sections, and only those sections containing the SVZ were selected for additional manipulation. The SVZ was dissected along the lateral wall of the lateral ventricles under a surgical microscope, and then cut into small pieces (50-100 $\mu \mathrm{m}$ in size) that were placed on top of 50\% BD PuraMatrix Peptide Hydrogel (BD Biosciences, Franklin Lakes, NJ). Peptide Hydrogel was prepared following the manufacturer's recommendations. Briefly, $35 \mathrm{~mm}$ diameter cell inserts ( $0.4 \mu \mathrm{m}$ pore size; Corning, Corning, NY) were coated with Peptide Hydrogel diluted 1:1 with 1xPBS (pH7.4). After polymerization, the gel was equilibrated three times with neurobasal medium containing B27, $\mathrm{N} 2$ supplements, L-glutamine $(0.5 \mathrm{~mm})$ and penicillin-streptomycin (all from Invitrogen). Cultures were maintained in a humidified incubator at $5 \% \mathrm{CO}_{2}$ and $37^{\circ} \mathrm{C}$ for $4 \mathrm{~d}$ in vitro. SVZ explants were cocultured with heparin bead (Sigma, St Louis, MO) loaded with EGF $(2 \mu \mathrm{g} / \mathrm{ml})$ and control (0.1\% BSA; Sigma) proteins. Explants were symmetrically positioned in between EGF- and BSA-loaded beads $(300-400 \mu \mathrm{m}$ from each set of beads), using a graticulate with scale division. This configuration allowed the simultaneous analysis of $\mathrm{EGFP}^{+}$cell migration with the two sets of beads. For direct quantification of cell migration, SVZ explants were subdivided into four quadrants, and the areas occupied by migrating cells in two of these quadrants (facing either BSA- or EGF-coated beads) were quantified by image analysis as previously described (Pozas et al., 2001). The same results were also obtained by separately testing individual explants with EGF- and BSA-loaded heparin beads.

In a separate set of experiments, the original SVZ explants were scraped off the culture dish at $72 \mathrm{~h}$ days after plating, and CNP-EGFP ${ }^{+}$ cells that had migrated out of the explants and had remained attached to the dish were FACS-purified. These cells were then used to grow clonal neurospheres ( 5 cells $/ \mu \mathrm{l}$ ) (Aguirre and Gallo, 2004) for 6-7 d, and then plated in differentiation medium to determine their lineage potential (Aguirre and Gallo, 2004; Aguirre et al., 2004).

Fluorescence activated cell sorting (FACS). FACS-purification of $\mathrm{NG}^{+} / \mathrm{EGFP}^{+}$and $\mathrm{NG}^{+} / \mathrm{GFP}^{+}$cells has been previously described in detail (Belachew et al., 2002; Aguirre and Gallo, 2004). Tissue from P8 CNP-EGFP, $\beta$-actin-GFP, CNP-hEGFR, or CNP-hEGFR/Tg ActbGFP mice was dissociated to a single cell suspension, followed by immunostaining for NG2 (Aguirre et al., 2004). To fluorescence-activated cell sorter (FACS) purify NG2 ${ }^{+}$cortical cells transfected with an hEGFR or a constitutively active human EGFR (hEGFRviii) construct (see below), anti-NG2 (Chemicon, Temecula, CA), and anti-hEGFR (Biofluids, Camarillo, CA) antibodies were used in combination with appropriate R-phycoerytrin (PE)-conjugated and PE- cyanine 5.5 (Сy5.5)conjugated secondary antibodies, respectively (Caltag, Burlingame, CA). To FACS purify $\mathrm{NG}_{2}{ }^{+}$cortical cells transfected with phosphorylated cytomegalovirus (pCMV)-internal ribosomal entry site (IRES)-GFP (mock-GFP), anti-NG2 antibodies and GFP expression were used (Belachew et al., 2002; Aguirre and Gallo, 2004). Cell suspensions were analyzed for light forward and side scatter using an FACStar plus instrument (Becton Dickinson, Franklin Lakes, NJ).

Chemotaxis assays in Boyden chambers. FACS-purified NG2 ${ }^{+}$cells were obtained from the SVZ or the cerebral cortex of P8 CNP-EGFP mice (Aguirre and Gallo, 2004). Cortical transfected $\mathrm{NG}^{+} / \mathrm{GFP}^{+} / \mathrm{hEGFR}^{+}$, and $\mathrm{NG}^{+} / \mathrm{GFP}^{+} / \mathrm{hEGFR}^{+}$viii and $\mathrm{NG}^{+} /$mock-GFP ${ }^{+}$cells were FACS purified as described above. All NG2 ${ }^{+}$cells were resuspended at $1 \times 10^{6} \mathrm{cells} / \mathrm{ml}$ in stem cell medium $(\mathrm{SCM})$ (serum-free DMEM/F-12) supplemented with N2 and B27 (Invitrogen) for chemotaxis assays. In vitro migration of $\mathrm{NG}_{2}^{+}$cells was assessed using poly-L-lysine-, laminin-, vitronectin-, or fibronectin-coated (used at 5, 2, and $5 \mu \mathrm{g} / \mathrm{ml}$, 
respectively) polyvinylcarbonate-free membranes with $8 \mu \mathrm{m}$ pore size (Neuroprobe, Gaithersburg, MD). Assays were performed in modified Boyden chambers. Briefly, $25 \mu$ l of a solution containing $1 \times 10^{6}$ cells $/ \mathrm{ml}$ in SCM was placed in the upper chamber. Growth factors, including EGF (10 ng/ml), TGF $\alpha(10 \mu \mathrm{g} / \mathrm{ml})$, basic FGF (bFGF) $(10 \mu \mathrm{g} / \mathrm{ml})$, or plateletderived growth factor (PDGF) $(10 \mu \mathrm{g} / \mathrm{ml})$ were all diluted in DMEM/ F-12 and added to the lower chamber in DMEM/F-12 or to both chambers when indicated. In the experiments in which EGFR blockers were used, cells were preincubated with the inhibitors for $30 \mathrm{~min}$ at $37^{\circ} \mathrm{C}$ in $5 \%$ $\mathrm{CO}_{2}$ before loading in the top chamber. Blockers included the following: (1) the cell-permeable, irreversible and selective inhibitor of EGFR tyrosine kinase activity PD168393 (4-[3(bromophenyl)-amino]-6acrylamidoquinazoline), which does not inhibit other kinases (Calbiochem, La Jolla, CA); (2) selective anti-hEGFR (clone LA1, catalog \#05101) or anti-EGF-neutralizing antibodies (catalog \#06-102) (both from Upstate, Charlottesville, VA), and (3) the arginine-glycine-aspartate (RGD) peptide inhibitor of integrin-ligand interactions (Calbiochem). After overnight incubation $(12 \mathrm{~h})$ at $37^{\circ} \mathrm{C}$ in $5 \% \mathrm{CO}_{2}$, the upper surface of membranes was scraped free of cells and debris, and membranes were air dried, fixed, and mounted. Cells that had migrated through the pores and adhered to the membrane were analyzed under high-power light microscopy and counted in five to six adjacent high-power fields (HPFs) (area of HPF, $0.78 \mathrm{~mm}^{2}$; area of each filter, $7.07 \mathrm{~mm}^{2}$ ) in triplicate (three different membranes for each experimental condition). Experiments were repeated three times, and data were analyzed from a total of 45-54 fields from nine membranes for each experimental condition. Data were expressed as numbers of cells per HPF \pm SEM. Data were analyzed for statistical significance between groups by using the unpaired $t$ test.

Bromodeoxyuridine pulse and terminal deoxynucleotidyl transferasemediated biotinylated UTP nick end labeling assays. FACS-purified NG2 ${ }^{+}$ cells were seeded $(25,000$ cells per well) in 24-well culture plates precoated with laminin. Cells were cultured in SCM for $12 \mathrm{~h}$ in the presence or absence of EGF $(10 \mathrm{ng} / \mathrm{ml})$. Cells were pulsed with $10 \mu \mathrm{M}$ bromodeoxyuridine (BrdU) for $12 \mathrm{~h}$ before fixation. BrdU immunostaining and terminal deoxynucleotidyl transferase-mediated biotinylated UTP nick end labeling (TUNEL) assay were performed as described previously (Aguirre et al., 2004).

Antibodies and immunohistochemistry. Freshly cut, floating tissue sections $(50 \mu \mathrm{m})$ from P8 mice were prepared as described previously (Aguirre et al., 2004). Primary antibody dilutions were as follows: $0.5 \mu \mathrm{g} / \mathrm{ml}$ for the specific anti-hEGFR (Biofluids); 1:50 for the anti-EGFR (Upstate) and anti-BrdU (BD Biosciences); 1:100 for the anti-caveolin (Santa Cruz Biotechnology, Santa Cruz, CA); 1:200 for anti-EGF (Chemicon); and 1:500 for anti-NG2 antibody (Chemicon), anti-Ki-67 (Novocastra, Newcastle, UK), anti- $\beta$-catenin (BD Biosciences), anti-N-cadherin (BD Biosciences), anti-caspase 3 (Cell Signaling Technology, Beverly, MA), antiGFP (Clontech, Palo Alto, CA), and anti-GFAP (Sigma, St. Louis, MO). Nuclear staining was performed using TO-PRO (Invitrogen).

Western blot analysis. FACS-purified NG2 ${ }^{+}$cells were used for protein extraction using lysis buffer [50 mm Tris- $\mathrm{HCl}$, pH 7.5, 1 mм EDTA, 1 mm EGTA, $1 \mathrm{~mm}$ sodium orthovanadate, $50 \mathrm{~mm}$ sodium fluoride, $0.1 \%$ 2 -mercaptoethanol, and $1 \%$ Triton X-100, plus proteases inhibitor cocktail (Sigma)]. Protein samples $(20 \mu \mathrm{g})$ were separated on GENE Mate express Gels 4-20\% (ISC BioExpress, Kaysville, UT) and transferred to polyvinylidene difluoride membranes (Millipore, Bedford, MA). hEGFR, EGFR, and EGF bands were detected using an enhanced chemiluminescence substrate mixture (ECL Plus; Amersham Biosciences, Buckinghamshire, UK). A selective primary anti-human EGFR (Biofluids), anti-EGFR (Upstate), anti-EGF (Chemicon), and antiphosphorylated extracellular signal-regulated kinase (pERK) (Cell Signaling Technology) antibodies were used in combination with a secondary horseradish peroxidase conjugate (Jackson ImmunoResearch, West Grove, PA).

DNA constructs and transfection procedure. Cortical cell cultures were prepared from P8 Tg ActbGFP or from FVB/NxCB6 [wild type (wt)] mouse brains. Cortical tissue was dissociated to a single cell suspension (Aguirre et al., 2004) and plated onto poly-L-lysine precoated $60 \mathrm{~mm}$ dishes at a density of $1.5 \times 10^{6} \mathrm{cell} / \mathrm{ml}$ in DMEM/10\% FCS medium for $12 \mathrm{~h}$ before transfection. For cell transfection, CMV promoter vectors containing the cDNA of the wild-type hEGFR (Upstate) and of the constitutive active EGFR (pLTR-EGFRviii) (Schmidt et al., 1998) were used. A pCMV-IRES-GFP (Clontech) vector was used as a mock plasmid in controls. All plasmid constructs were introduced into cultured cortical cells by Lipofectamine-mediated transfection (GTS, San Diego, CA), using $3 \mu \mathrm{g}$ of DNA and $10 \mu \mathrm{l}$ of liposomes in OptiMEM (Invitrogen). The duration of the transfection was $8 \mathrm{~h}$. After transfection, the culture medium was changed to DMEM/10\% FBS for $36 \mathrm{~h}$, and cells were harvested and then processed for double immunostaining with anti-NG2 and antihEGFR antibodies. The anti-hEGFR antibody that was used specifically recognizes the wt and the constitutively active hEGFRs and does not react with the murine EGFR (Biofluids). Cells were then FACS purified as described above.

Transplantation and analysis of grafted cells. Wild-type P4 FVB/NxCB6 pups were used as recipients. Donor cells included the following: (1) FACS-purified P8 $\mathrm{NG}^{+} / \mathrm{GFP}^{+}$cells from the $\beta$-actin-GFP mouse strain (Aguirre and Gallo, 2004); (2) FACS-purified P8 SVZ or cortical $\mathrm{NG}_{2}{ }^{+}$cells from the CNP-hEGFR mouse strain (Ling et al., 2005); (3) FACS-purified P8 cortical NG2 ${ }^{+} / \mathrm{GFP}^{+}$cells from the CNP-hEGFR mouse strain crossed with the $\beta$-actin-GFP mouse strain (CNPhEGFR/Tg ActbGFP mouse); (4) cultured cortical NG2 ${ }^{+} / \mathrm{GFP}^{+}$cells from $\beta$-actin-GFP mice transfected with the hEGFR or the hEGFRviii construct $\left(\mathrm{NG}^{+} / \mathrm{GFP}^{+} / \mathrm{hEGFR}^{+}\right.$and $\mathrm{NG}^{+} / \mathrm{GFP}^{+} / \mathrm{hEGFR}^{+}$viii, respectively); and (5) cultured cortical NG2 ${ }^{+}$cells from FVB/NxCB6 mice transfected with the pCMV-IRES-GFP construct $\left(\mathrm{NG}^{+} /\right.$mock-GFP $\left.{ }^{+}\right)$. Immediately after FACS, cells were washed with DMEM plus $10 \%$ FCS and resuspended in DMEM at 20,000 cells/ $\mu$ l. Microinjection was performed under deep hypothermia, and $1 \mu \mathrm{l}$ of the cell suspension was injected directly into the ventricles. In some experiments, trypan blue $(0.1 \%)$ was added to the cell suspension to confirm targeting of injections. The injection was performed with a glass capillary pipette (100$150 \mu \mathrm{m}$ outer diameter with beveled tip) driven by a Harvard Instruments (Murrieta, CA) micromanipulator. In the grafting experiments using donor cortical cells from the CNP-hEGFR mouse, cells were also stained with chloromethylbenzamido-DiI (Invitrogen), as recommended. Briefly, NG2 ${ }^{+} / \mathrm{CNP}^{\mathrm{hEGFR}}{ }^{+}$cells were incubated for $5 \mathrm{~min}$ with DiI ( $1 \mu \mathrm{g} / \mathrm{ml}$; Invitrogen $)$ at $37^{\circ} \mathrm{C}$ and then placed on ice for $15 \mathrm{~min}$. The reaction was stopped with basal DMEM medium, and cells were washed twice with DMEM. For migration and anatomical distribution studies, mice were maintained for 7-10 d after the cell graft and processed for immunohistochemistry as described previously (Aguirre et al., 2004). Cells derived from grafted $\mathrm{NG}^{+} / \mathrm{GFP}^{+}$cells or from transfected cells were readily visible under confocal microscopy in unstained tissue, using a $488 \mathrm{~nm}$ laser-line excitation. Cells derived from wt/NG2 ${ }^{+} / \mathrm{mock}^{-}$ $\mathrm{GFP}^{+}$cells were visualized after anti-GFP immunostaining with an antiGFP rabbit polyclonal antibody (IgG, 1:500; Clontech), as described previously (Aguirre et al., 2004). The percentages of total transplanted $\mathrm{GFP}^{+}$or $\mathrm{DiI}^{+}$cells found in striatum, SCWM, wall of the LV, SVZ, RMS, fimbria, $\mathrm{OB}$, and hippocampus were quantified in three separate experiments as described below.

For analysis of cell differentiation 4 weeks after transplantation, neuronal-specific nuclear protein (NeuN), CNP, and GFAP antibodies were used as cell markers to identify neurons, oligodendrocytes, and astrocytes, respectively. For counting of cells derived from transplanted cortical NG2 ${ }^{+} / \mathrm{hEGFR}^{+} / \mathrm{EGFP}^{+}$cells, $\mathrm{EGFP}^{+}$cells were counted in different brain regions. Cell numbers were obtained by analyzing a total of 1850 cells in 300 sections ( $40 \mu \mathrm{m}$ thickness) from three different experiments (three different brains). Cell counting data in tissue sections were expressed as averages \pm SEM. Statistical analysis was performed by paired $t$ test.

Microscopy and cell counting. An Olympus Optical (Melville, NY) BX60 fluorescence inverted microscope was used to visualize immunofluorescence in cultured cells. Images were acquired using a $40 \times$ objective. For analysis in tissue sections, a Bio-Rad (Hercules, CA) MRC 1024 confocal laser-scanning microscope equipped with a krypton-argon laser and an Olympus Optical IX-70 inverted microscope were used to image localization of FITC (488 nm laser-line excitation; 522/35 emission filter), Texas Red (568 nm excitation; 605/32 emission filter), and 

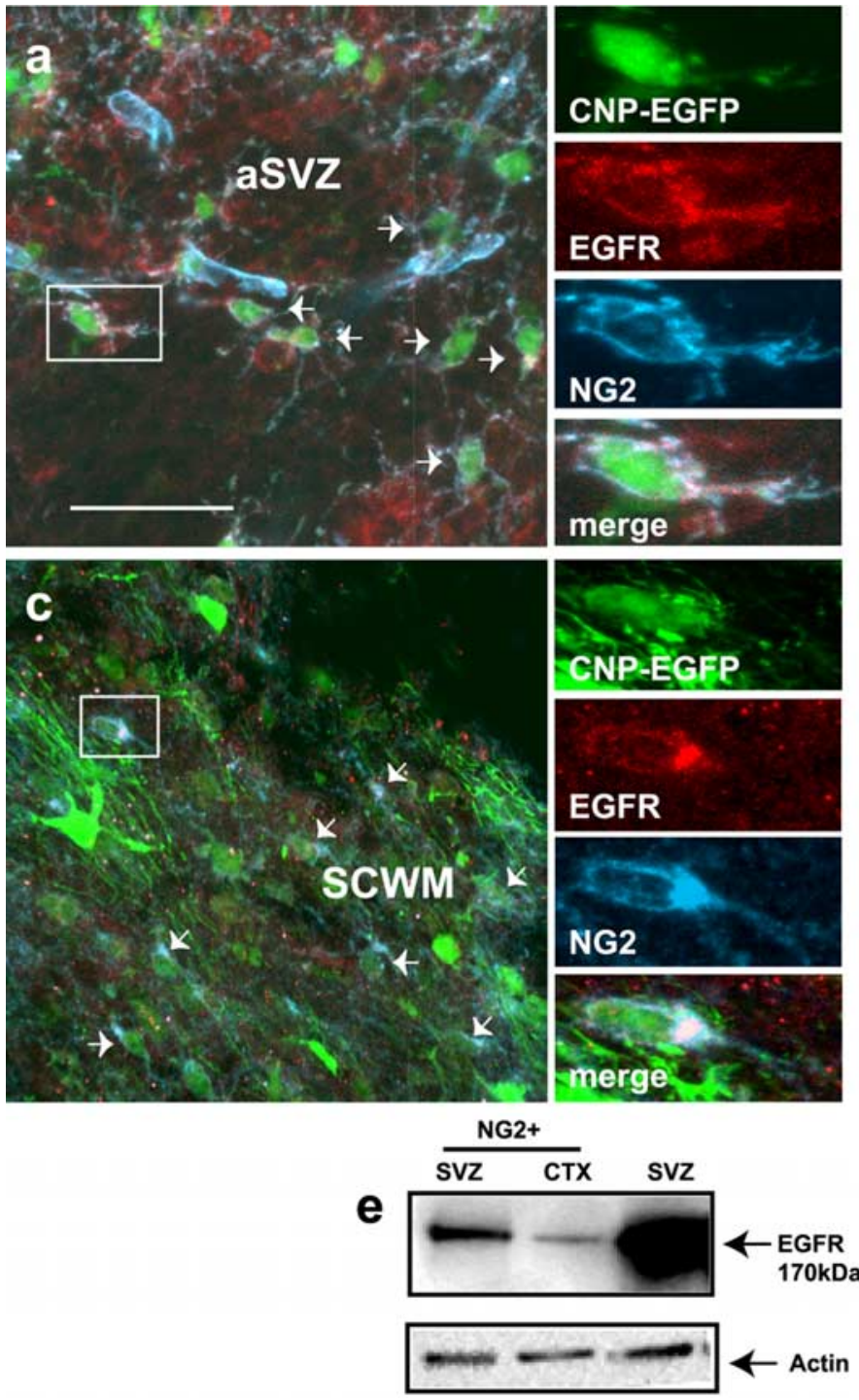
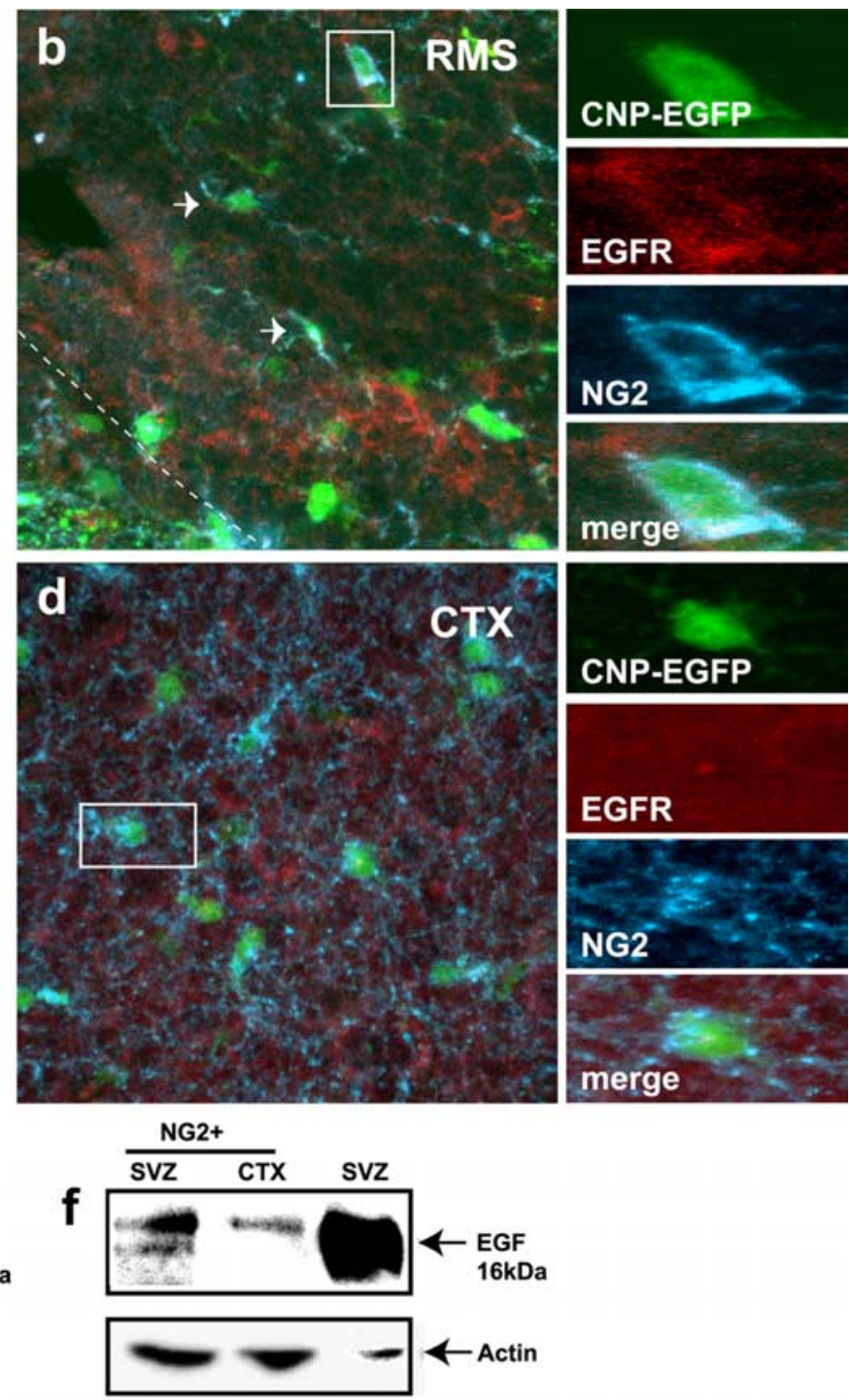

Figure 1. Expression of EGFR and EGF in NG2 ${ }^{+}$cells of the postnatal brain. Immunostaining of sagittal sections from P8 CNP-EGFP mouse brains. aSVZ, Anterior SVZ; CTX, cerebral cortex. NG2 ${ }^{+}$ cells express high levels of EGFR in the SVZ (a), RMS (b), and SCWM (c), respectively. Conversely, coronal sections show that, in cerebral cortex (d) , NG2 ${ }^{+}$cells express levels of EGFR undetectable by immunohistochemistry. The individual cells selected for multi-marker illustration are indicated as boxed areas. Additional arrows indicate triple-positive cells. Dotted lines indicate the borders of the RMS. Optical sections $(Z=0.5 \mu \mathrm{m} ; X=30 \mu \mathrm{m})$ of confocal epifluorescence images were sequentially acquired using a $60 \times$ oil objective (NA, 1.40) with Bio-Rad LaserSharp version 3.2 software. Confocal Assistant 4.02 was used to merge images. Merged images were processed in Photoshop 7.0 with minimal manipulations of contrast. Scale bar, $50 \mu \mathrm{m} . \boldsymbol{e}, \boldsymbol{f}$, Total protein extracts from FACS-purified NG2 ${ }^{+}$cells were analyzed by Western blot with selective anti-EGFR $(\boldsymbol{e})$ and anti-EGF $(\boldsymbol{f})$ antibodies. SVZ NG2 ${ }^{+}$cells express EGFR and EGF levels higher than cortical cells. SVZ tissue was used as a positive control. The blotted membrane was reprobed with anti-actin antibodies to determine equal protein loading (bottom panels).

Cy5 (647 excitation; 680/32 emission filter). Optical sections $(Z=0.5$ $\mu \mathrm{m}$ ) of confocal epifluorescence images were sequentially acquired using a $40 \times$ [numerical aperture (NA), 1.35], a $60 \times(\mathrm{NA}, 1.40)$, or $100 \times$ oil objective (NA, 1.35) with Bio-Rad LaserSharp version 3.2 software. Confocal Assistant 4.02 was used to merge images. Merged images were processed in Photoshop 7.0 (Adobe Systems, San Jose, CA) with minimal manipulations of contrast.

For cell counting in cultured cells, averages were obtained from three separate sets of cultures. In each culture, at least 10 separate microscopic fields $\left(248 \mu \mathrm{m}^{2}\right)$ were analyzed. For $\mathrm{GFP}^{+}$and $\mathrm{DiI}^{+}$cells in tissue sections, cells were counted in the striatum, SCWM, wall of the LV, SVZ, RMS, fimbria, OB, and hippocampus 1 week after grafting. The anatomical distribution of $\mathrm{GFP}^{+}$and $\mathrm{DiI}^{+}$cells was analyzed in $Z$-series confocal scanning images [20-30 $\mu \mathrm{m}$ thickness; step size, $0.5 \mu \mathrm{m}$ between successive images of the same field $\left.\left(228 \mu \mathrm{m}^{2}\right)\right]$. Cell numbers were obtained by analyzing the entire brain after grafting, i.e., an average of 144 total tissue sections per brain ( $40 \mu \mathrm{m}$ thickness) from at least three to four independent grafting experiments (three to four different brains total). The total number of graft-derived cells per brain ranged between 1400 and 1600 for any of the transplanted cell populations (Aguirre and Gallo, 2004). The number of cells found in each region was expressed as percentage of the total number of graft-derived cells found in each brain. Cell counting data in tissue sections are expressed as averages \pm SEM. Statistical analysis was performed by unpaired $t$ test.

\section{Results}

\section{EGF and EGFR expression in $\mathrm{NG}_{2}{ }^{+}$progenitor cells}

We examined expression of EGFR and EGF in $\mathrm{NG}^{+}$cells by immunostaining tissue sections of P8 CNP-EGFP mouse brains (Aguirre and Gallo, 2004; Aguirre et al., 2004). A large percentage of $\mathrm{NG}^{+}$cells in the SVZ, RMS, and SCWM expressed EGFRs (Fig. $1 a-c$ ), but expression in cortical NG2 ${ }^{+}$cells was undetectable (Fig. 1d). Virtually all NG2 ${ }^{+}$cells of the SVZ were immunopositive for EGFR and its ligand EGF (Aguirre and Gallo, unpublished observation) (Aguirre et al., 2004). Western blot 

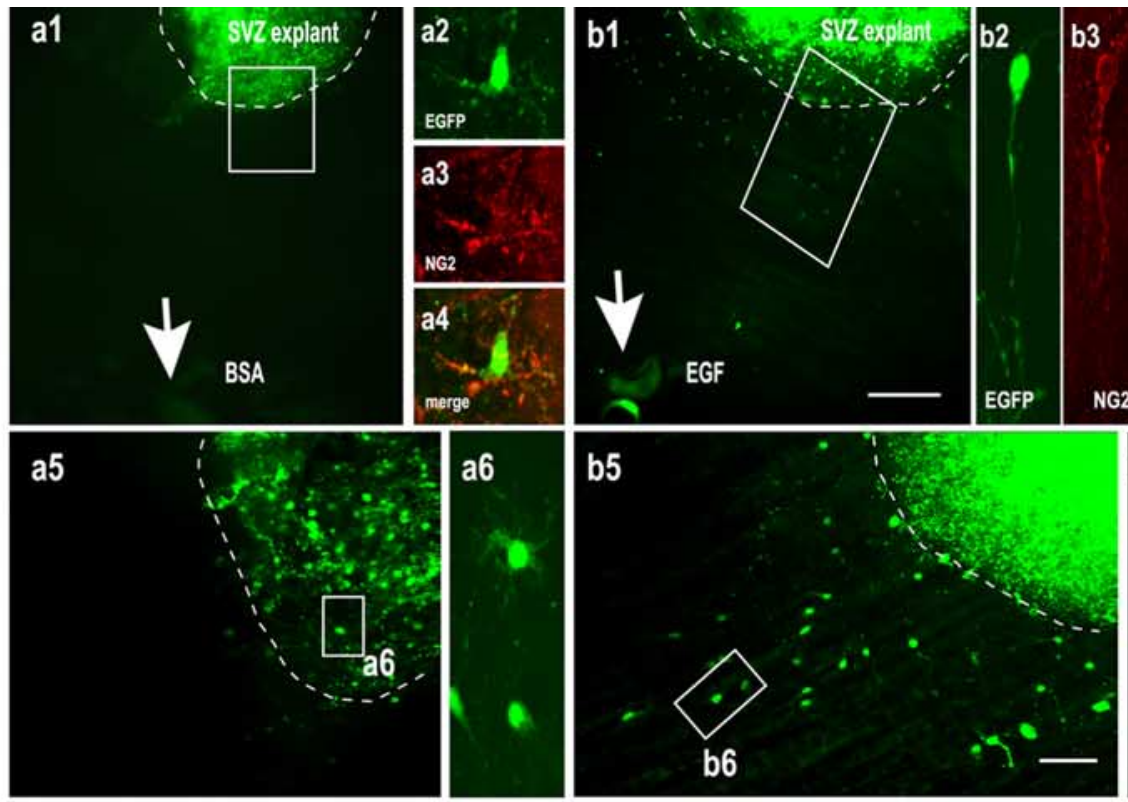

C1

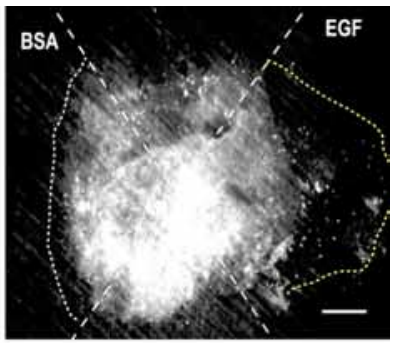

C2
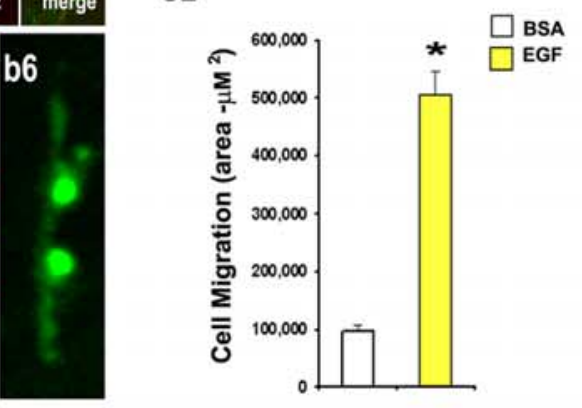

d

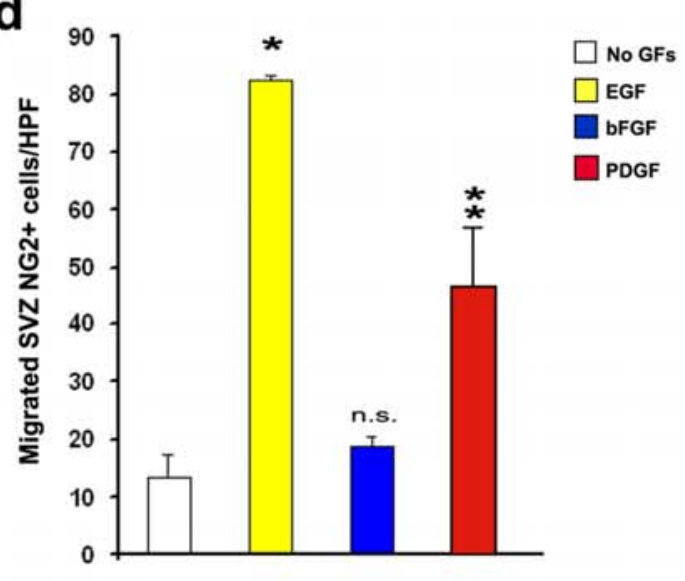

e

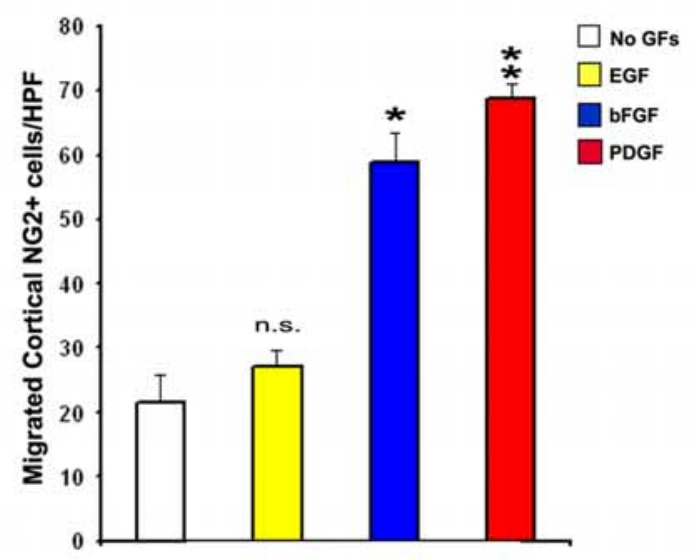

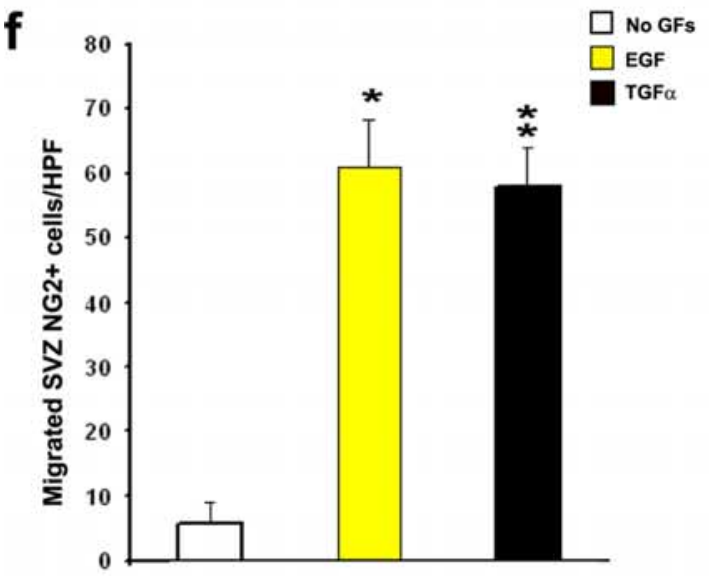
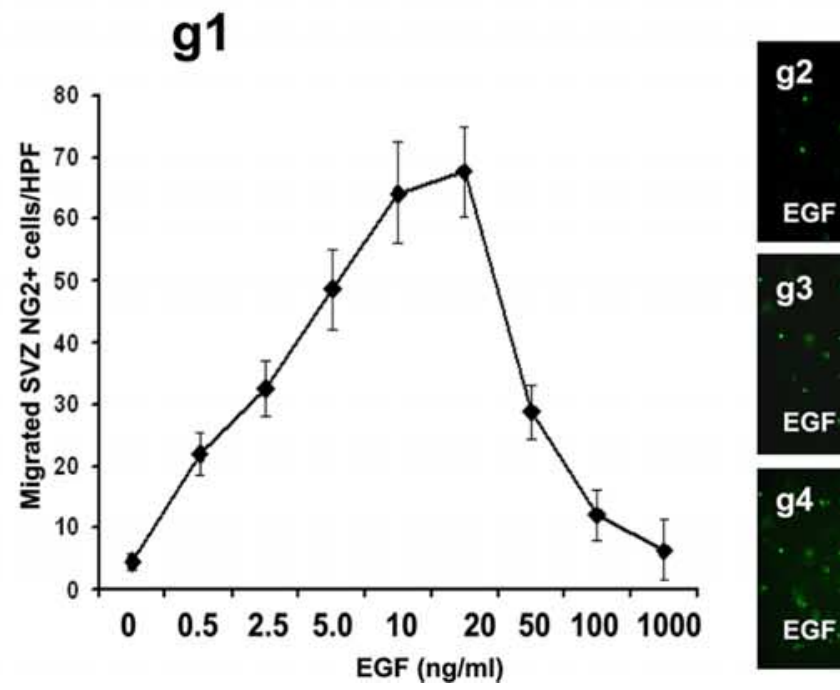

EGF 0.0ng
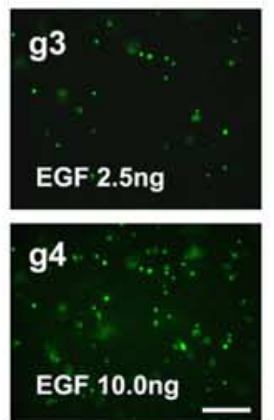

Figure 2. EGF promotes migration of SVZNG2 ${ }^{+}$cells. SVZ explants from the CNP-EGFP mouse were cocultured with BSA-soaked ( $\boldsymbol{a}$ ) and EGF-soaked $(\boldsymbol{b})$ heparin beads. EGFP ${ }^{+}$cells preferentially migrate toward EGF $(\boldsymbol{b})$ compared with BSA beads $(\boldsymbol{a})$. Arrows in $\boldsymbol{a} 1$ and $\boldsymbol{b} 1$ point to the position of the soaked bead. Dotted lines indicate the edges of the SVZ explants. High-magnification images obtained from the boxed areas in $\boldsymbol{a} \mathbf{1}$ and $\boldsymbol{b} \boldsymbol{1}$ are shown in $\boldsymbol{a} \mathbf{5}$ and $\boldsymbol{b 5}$, respectively. High-magnification images obtained from the boxed areas in $\boldsymbol{a} \boldsymbol{5}$ and $\boldsymbol{b} \boldsymbol{5}$ are shown in $\boldsymbol{a} \boldsymbol{6}$ and $\boldsymbol{b} \boldsymbol{6}$, respectively. $A$ large percentage of the EGFP ${ }^{+}$cells that were migrating in the presence of EGF (b2-b4) or remained within the explant with BSA (a2-a4) were NG2 ${ }^{+}$. Migratory cells with EGF $(\boldsymbol{b} 2-\boldsymbol{b 4}$, $\boldsymbol{b} \mathbf{6})$ displayed a bipolar morphology distinct from nonmigratory cells with BSA $(\boldsymbol{a 2}-\boldsymbol{a} \mathbf{4}, \boldsymbol{a b})$. c, Quantification of NG2 ${ }^{+}$cell migration in SVZ explants. c1, A representative SVZ explant from the CNP-EGFP 
a

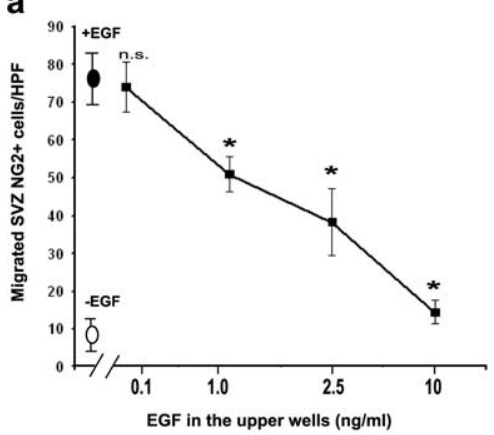

c1

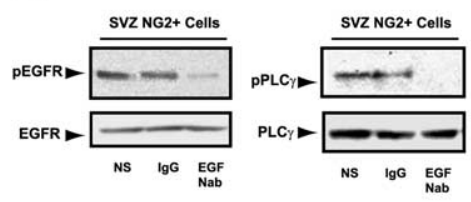

c2

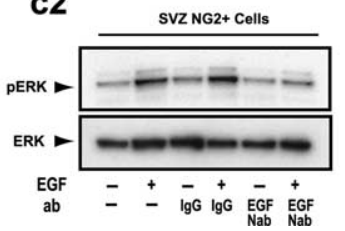

b

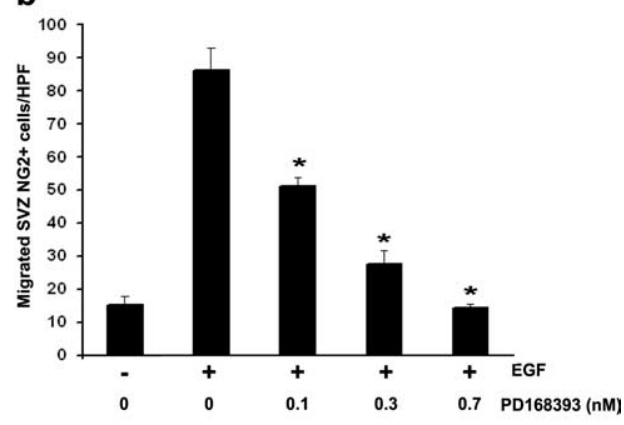

d

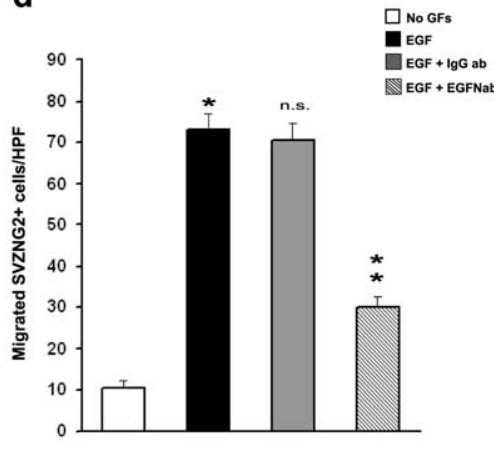

Figure 3. The EGFR is directly involved in migration of SVZNG2 ${ }^{+}$cells. NG2 ${ }^{+} / \mathrm{EGFP}^{+}$cells were FACS purified from the SVZ of P8 CNP-EGFP mice. $\boldsymbol{a}$, Migration of NG2 ${ }^{+}$cells depends on the EGF concentration gradient. Cell migration was measured in the presence of EGF in the lower chamber (dark circle, $10 \mathrm{ng} / \mathrm{ml})$. The addition of EGF in the upper chamber (1-10 $\mathrm{ng} / \mathrm{ml}$ ) progressively reduces directional cell migration induced by EGF in the lower chamber. Cell migration in the absence of EGF was also measured (white oval). Unpaired $t$ test compared with EGF in the lower chamber only, ${ }^{*} p<0.001$; n.s., not significant. All data are represented as averages \pm SEM of triplicate determinations in at least three independent experiments. $\boldsymbol{b}$, The EGFR blocker PD168393 inhibits migration of NG2 ${ }^{+}$cells toward EGF $(10 \mathrm{ng} / \mathrm{ml})$ in a dose-dependent manner. Cells were preincubated with the PD168393 inhibitor for $30 \mathrm{~min}$ before seeding the cells in microchemotaxis chambers. Migration was assayed after $12 \mathrm{~h}$. Unpaired $t$ test compared with EGF alone, ${ }^{*} p<0.001$. All data are represented as averages \pm SEM of triplicate determinations in at least three independent experiments. $\boldsymbol{c}$, The EGF-neutralizing antibody silences EGFR-associated signaling. Cells were preincubated with the EGF-neutralizing antibody (EGFNab; $2 \mu \mathrm{g} / \mathrm{ml})$ or rabbit lgG $(2 \mu \mathrm{g} / \mathrm{ml})$ for $30 \mathrm{~min}$, before stimulation with EGF $(10 \mathrm{ng} / \mathrm{ml})$. C1, Western blots using specific anti-phospho-EGFR and anti-EGFR antibodies and anti-phospho-PLC $\gamma$ antibodies. Incubation of freshly purified SVZ NG2 ${ }^{+}$cells with anti-EGF neutralizing antibodies suppressed EGFR-associated signaling, as demonstrated by EGFR and PLC $\gamma$ phosphorylation. The membranes were reprobed to show that equal levels of proteins were loaded, as shown by the antibody against total EGFR and total PLC $\gamma$ (bottom panels). c2, Western blot using specific antibodies for pERK or total ERK. Incubation of purified SVZ NG2 ${ }^{+}$cells with EGF caused ERK phosphorylation, which was blocked by pretreatment with the anti-EGF neutralizing antibody (top). The membrane was reprobed to show that equal levels of proteins were loaded, as shown by the antibody against total ERK (bottom). $\boldsymbol{d}$, The EGF-neutralizing antibody (EGFNab) inhibits directional migration of NG2 ${ }^{+}$cells induced by EGF. Cells were preincubated with EGF-neutralizing antibody $(2 \mu \mathrm{g} / \mathrm{ml})$ or rabbit $\operatorname{lgG}(\mathrm{lgGab} ; 2 \mu \mathrm{g} / \mathrm{ml})$ for $30 \mathrm{~min}$ before stimulation with EGF (10 ng/ml). Migration was assayed after $12 \mathrm{~h}$. Unpaired $t$ test, EGF compared with no growth factors (No GFs), ${ }^{*} p<0.002$; EGF + IgGab and EGF + EGFNab compared with EGF, NS and ${ }^{* *} p<0.03$, respectively.

analysis of EGFR and EGF expression in FACS-purified NG2 ${ }^{+}$ cells showed that SVZ progenitors expressed much higher levels than their cortical counterpart (Fig. 1e,f). This pattern of EGFR and EGF expression in the SVZ and RMS was consistent with previously published data obtained by in situ hybridization and immunocytochemistry, respectively (Anton et al., 2004). Real-time quantitative PCR analysis of P8 SVZ and P8 brain demonstrated that, under our experimental conditions, both heparin binding EGF and TGF $\alpha$ RNAs were expressed at detectable levels in both tissues. Amphiregulin was detected only in the SVZ, but betacellulin, EGF, and epiregulin were undetectable in both SVZ and brain (K. Monk, A. Aguirre, N. Ratner, and V. Gallo, unpublished observation). Altogether, these data show that EGFR and appropriate ligands are expressed in $\mathrm{NG}_{2}{ }^{+}$cells of the SVZ, RMS, and SCWM and therefore may play a role in the migration of this highly motile class of postnatal cells (Aguirre and Gallo, 2004; Aguirre et al., 2004), as shown previously for VZ progenitors (Burrows et al., 1997).

\section{EGF promotes migration of SVZ NG2 ${ }^{+}$ cells through EGFR activation}

To determine whether EGFRs are involved in SVZ NG2 ${ }^{+}$cell migration, we placed SVZ explants from the CNP-EGFP mouse brain equidistantly $(300-400 \mu \mathrm{m})$ from ectopic sources of EGF and BSA, i.e., between heparin beads soaked with either recombinant EGF or BSA. This configuration allowed the simultaneous analysis of $\mathrm{EGFP}^{+}$cell migration with the two sets of beads (Fig. $2 a-c$ ). Under these conditions, a high percentage of $\mathrm{EGFP}^{+}$cells had already migrated out of the explant toward the EGF-soaked beads during the first $24 \mathrm{~h}$ in culture (data not shown). At $72 \mathrm{~h}$ in culture, $\mathrm{EGFP}^{+}$cells displayed very limited migration out of the explant toward BSA-heparin beads (Fig. 2a1-a6). Conversely, a large number of EGFP ${ }^{+}$cells exhibited migration toward the EGFheparin beads (Fig. 2b1-b6). Direct quantification of cell migration at $72 \mathrm{~h}$ was performed by measuring the area occupied by migrating $\mathrm{EGFP}^{+}$cells (Fig. $2 c 1, c 2$ ). This demonstrated a fivefold increase in EGF-stimulated migration compared with BSA (Fig. 2c2). Approximately $70 \%$ of the EGFP ${ }^{+}$ cells that were migrating in the presence of EGF were $\mathrm{NG2}^{+}$(Fig. $2 b 2-b 4$ ). Furthermore, only $\mathrm{EGFP}^{+}$cells that had migrated in the presence of EGF displayed a typical migratory morphology, with a small cell body and a thin cell process oriented toward the

$\leftarrow$

mouse cultured in hydrogel and exposed to BSA (left, white dotted line) or EGF (right, yellow dotted line). Scale bar, $300 \mu \mathrm{m}$. c2, Histograms illustrate quantification of cell migration in SVZ explants, shown as average \pm SEM of migrated area (in square micrometers). A total of 10 explants from three different experiments were analyzed. ${ }^{*} p<0.01$. $\boldsymbol{d}-\boldsymbol{g}$, Cell migration was determined using microchemotaxis chambers (Boyden chambers). In all of the cases, data represent averages \pm SEM of triplicate determinations from three different experiments. HPF, $40 \times$ magnification. $\boldsymbol{d}$, Different growth factors were used in the lower chamber to stimulate migration in SVZ NG2 ${ }^{+}$cells. Note that EGF has the strongest effect on $\mathrm{NG2}^{+}$cell migration. No GFs, No growth factors. Unpaired t test compared with no GFs, ${ }^{*} p<0.005,{ }^{* *} p<0.01$; n.S., not significant. $e$, Cortical NG2 ${ }^{+}$cells do not migrate in presence of EGF, but they do in the presence of bFGF and PDGF. Unpaired $t$ test compared with no GFs, ${ }^{*} p<0.0002,{ }^{* *} p<0.0005 . f$, TGF $\alpha$ promotes migration of SVZNG2 ${ }^{+}$cells to a similar extent as EGF. Unpaired $t$ test compared with no GFs, ${ }^{*} p<0.005,{ }^{* *} p<0.0001$. $\boldsymbol{g}$, Dose-response curve of the effect of EGF on SVZ NG2 ${ }^{+}$cell migration shows that the maximal effect of EGF occurs at $10-20 \mathrm{ng} / \mathrm{ml} . \boldsymbol{g} 2-\boldsymbol{g} 4$, Example of SVZ NG2 ${ }^{+}$cells that migrated through the filters with different concentrations of EGF. Scale bars, $50 \mu \mathrm{m}$. 
source of EGF (compare Figs. 2b2-b4,b6 with $a 6$ ). Finally, migratory $\mathrm{EGFP}^{+}$cells were still multipotential, as determined by FACS purification and clonal analysis in vitro (supplemental Fig. S1, available at www.jneurosci.org as supplemental material). These results strongly suggest that EGF promotes migration of multipotential SVZ NG2 ${ }^{+} / \mathrm{EGFP}^{+}$cells.

To determine the specificity of EGF in promoting migration of SVZ NG2 ${ }^{+}$cells, we used Boyden microchemotaxis chambers to compare the migratory behavior of FACS-purified $\mathrm{NG}^{+}$/ $\mathrm{EGFP}^{+}$cells from the SVZ and cortex in the presence of different growth factors (Fig. 2d,e). After $12 \mathrm{~h}$, the maximal migratory effect on SVZ cells was observed in the presence of EGF (Fig. 2d). PDGF promoted cell migration to a lesser extent than EGF, and bFGF had no effect (Fig. $2 d$ ). Conversely, cortical NG2 ${ }^{+}$cells did not migrate in the presence of EGF, but they did when exposed to PDGF or bFGF (Fig. 2e).

To investigate the ligand specificity of the EGF-mediated migration in SVZ NG2 ${ }^{+}$cells, we exposed these cells to TGF $\alpha$, another EGFR ligand present in the postnatal/adult SVZ (Kornblum et al., 1997; Junier, 2000). TGF $\alpha$ promoted chemoattraction to a similar extent as EGF (Fig. $2 f$ ). A dose-response curve of the effect of EGF on SVZ NG2 ${ }^{+}$cell migration showed that maximal effects were observed between 10 and $20 \mathrm{ng} / \mathrm{ml}$ (Fig. $2 g$ ). Consistent with other systems in which growth factors promote chemotaxis, concentrations higher than $20 \mathrm{ng} / \mathrm{ml}$ were ineffective (Fig. 2g1) (Facchiano et al., 2000). Importantly, EGF did not modify the mitotic index (percentage of $\mathrm{NG}^{+} / \mathrm{BrdU}^{+}$cells, $33 \pm 3 \%$ EGF vs $27 \pm 2 \%$ control; $p>0.07$, unpaired $t$ test) (supplemental Fig. S2, available at www.jneurosci.org as supplemental material) nor the rate of cell death (percentage of $\mathrm{NG}^{+} /$ $\mathrm{TUNEL}^{+}$cells, $1.31 \pm 0.5 \%$ EGF vs $1.5 \pm 0.5 \%$ control; $p>0.92$, unpaired $t$ test) (supplemental Fig. S2, available at www. jneurosci.org as supplemental material) of SVZ NG2 ${ }^{+}$cells during the time of the assay. Altogether, these results demonstrate that the observed EGF-induced migration was not attributable to an increase in the number of $\mathrm{NG}_{2}{ }^{+}$cells produced during the assay but rather to a direct promigratory effect of EGF.

Because the presence of a concentration gradient of a ligand is essential to maintain cell migration, we wanted to demonstrate that disruption of the EGF gradient prevented SVZ NG2 ${ }^{+}$cell migration. Therefore, we performed experiments in which the same concentration of EGF was added to both the lower and upper chambers of the Boyden assembly. As shown in Figure $3 a$, maximal cell migration was reduced in a dose-dependent manner by increasing concentrations of EGF added only to the upper chamber while maintaining the concentration of EGF in the lower chamber constant.

To verify that EGF-induced migration was directly mediated by the activation of EGFR, we first preincubated SVZ NG2 ${ }^{+}$cells with the specific EGFR inhibitor PD168393 (Fry et al., 1998) before plating. After this treatment, cell migration assessed in Boyden chambers was reduced in a dose-dependent manner (Fig. $3 b)$. In a separate set of experiments, we used an EGFneutralizing antibody, which binds to the EGF/EGFR complex and inhibits EGFR dimerization (Johnson et al., 2005; Varley et al., 2005). $\mathrm{NG}^{+}$cells were preincubated with this antibody to suppress autocrine activation of EGFRs through EGF synthesized by $\mathrm{NG}^{+}{ }^{+}$cells themselves (Fig. 1). The EGF-neutralizing antibody silenced EGFR activation in purified SVZ NG2 ${ }^{+}$cells, as demonstrated by EGFR phosphorylation and by EGFRassociated phospholipase $\mathrm{C} \gamma$ (PLC $\gamma$ ) phosphorylation (Fig. 3c1). Furthermore, the same EGF-neutralizing antibody also prevented EGF-induced ERK phosphorylation in purified SVZ
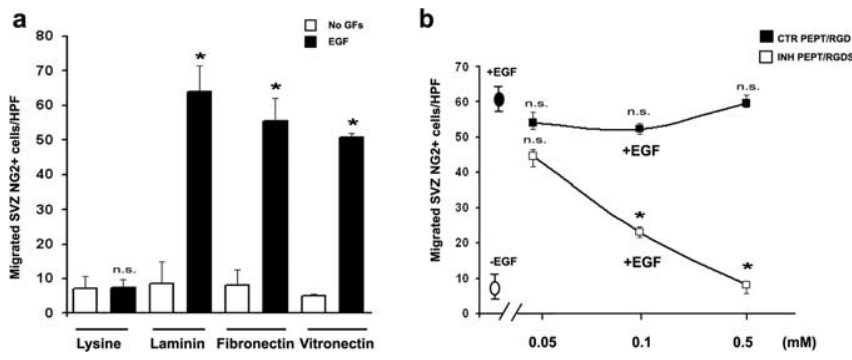

Figure 4. EGFR and ECM components coparticipate to promote SVZ NG2 ${ }^{+}$cell migration. $\mathrm{NG2}^{+} / \mathrm{EGFP}^{+}$cells were FACS purified from the SVZ of P8 CNP-EGFP mice. $\boldsymbol{a}$, EGF promotes directional migration in the presence of different extracellular matrix components but not in the presence of poly-L-lysine. Unpaired $t$ test compared with no growth factors (No GFs), ${ }^{*} p<$ 0.001 ; n.S., not significant. $\boldsymbol{b}$, EGF-induced directional migration involves integrin proteins. $\mathrm{NG2}^{+}$cells were mixed with RGDS (integrin binding inhibitor, white squares) or RGD peptides (control peptide, dark squares) at the indicated doses, before loading onto the chambers. Cell migration with $(10 \mathrm{ng} / \mathrm{ml})$ or without EGF is indicated with black and white ovals, respectively. Unpaired $t$ test, compared with EGF alone, ${ }^{*} p<0.001$.

$\mathrm{NG}_{2}{ }^{+}$cells in culture (Fig. $3 c 2$ ). After treatment with the EGFneutralizing antibody, $\mathrm{NG}^{+}$cell migration was reduced by $\sim 60 \%$ (Fig. $3 d$ ).

Altogether, these results are consistent with the interpretation that EGF and EGFR promote SVZ NG2 ${ }^{+}$cell migration.

\section{EGFR and extracellular matrix components coparticipate to promote $\mathrm{SVZ} \mathrm{NG}{ }^{+}$cell migration}

It has been described previously that EGFR-mediated migration entails the association of extracellular matrix (ECM) components with cell surface integrins (Hintermann et al., 2001). To determine whether EGFR-mediated migration in $\mathrm{NG}_{2}{ }^{+}$cells involved the ECM, we performed our chemotaxis assay in the presence of different ECM components. All of the assays described in Figures 2 and $3, a, b$, and $e$, were routinely performed with filters coated with laminin. Figure $4 a$ shows that EGF promoted SVZ NG2 ${ }^{+}$ cell migration only when cells were placed in chambers with filters coated with ECM components (laminin, fibronectin, and vitronectin) but not with poly-L-lysine, indicating that the ECM plays an important role in EGF-induced migration of $\mathrm{NG}^{+}$ cells.

The RGD sequence of many ECM proteins, including fibronectin and vitronectin, has been shown to directly interact with cell surface receptor integrins (Buckley et al., 1999). Synthetic RGD peptides can block such matrix-integrins interaction. To identify whether the ECM-dependent effects of EGF were mediated by integrins, SVZ NG2 ${ }^{+}$cells were incubated with RGDS peptides before they were placed in the chemotaxis chamber. EGF-induced directional migration of $\mathrm{NG}^{+}$cells on fibronectin-coated (Fig. 4b) or laminin-coated (data not shown) filters was blocked by RGDS peptides in a dose-dependent manner but not by the control peptide RGD, which does not bind to the functional integrin domain (Fig. $4 b$ ). In all of the microchamber assays described above, cell viability was determined by using trypan blue before cell plating (data not shown) and by TUNEL after the assay. Cell viability was similar in all of the experimental conditions tested (data not shown). In conclusion, our results are consistent with the interpretation that EGFR and ECM components coparticipate to promote $\mathrm{SVZ} \mathrm{NG}{ }^{+}$cell migration.

\section{In vivo migration of grafted SVZ $\mathrm{NG}^{+}{ }^{+}$cells in the postnatal brain depends on EGFR activity}

We have shown previously that SVZ NG2 ${ }^{+}$cells isochronically transplanted into the P4 LV display extensive rostral and caudal 

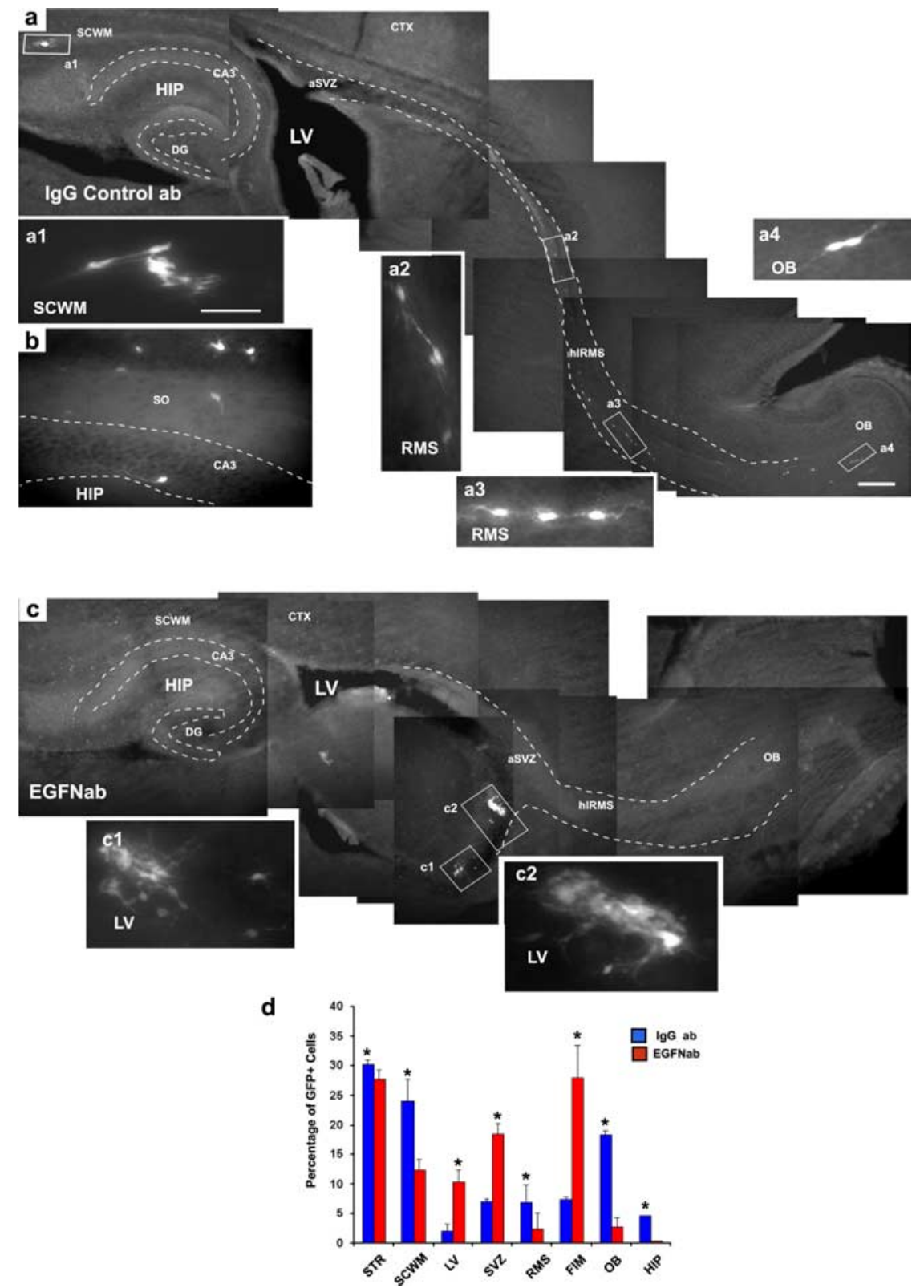

Figure 5. EGF-dependent migration of grafted SVZ NG2 ${ }^{+}$cells. NG2 ${ }^{+} / \mathrm{GFP}^{+}$cells were FACS purified from the SVZ of P8 Tg ActbGFP mice and transplanted into the LV of P4 wild-type host mice. Brains were analyzed 1WAT. GFP ${ }^{+}$cells were visualized by fluorescence microscopy. $\boldsymbol{a}$, Cells were treated with a control anti-lgG antibody before transplantation. Migrating GFP ${ }^{+}$cells were found throughout the RMS $(\boldsymbol{a} 2, \boldsymbol{a} 3)$ and in the $\mathrm{OB}(\boldsymbol{a} 4)$. Graft-derived GFP ${ }^{+}$cells were also found in the SCWM (a1) and in the CA3 and stratum oriens (SO) of the hippocampus (b). c, FACS-purified NG2 ${ }^{+} / \mathrm{GFP}^{+}$cells were preincubated with the EGF-neutralizing antibody (EGFNab) before transplantation into the LV. Grafted NG2 ${ }^{+} / \mathrm{GFP}^{+}$cells treated with the EGF-neutralizing antibody did not migrate, and the majority of grafted cells were found attached to the parenchyma and in the ependymal layer of the LV $(\mathbf{c} 1, \mathbf{c 2})$. Dotted lines depict the RMS and hippocampus $(\boldsymbol{a}, \boldsymbol{c})$ and the CA3 area of the hippocampus $(\boldsymbol{b})$. Scale bars: $\boldsymbol{a}, \boldsymbol{c}, 300 \mu \mathrm{m} ; \boldsymbol{a} \mathbf{1}$, all insets, $50 \mu \mathrm{m} . \boldsymbol{d}$, Histograms represent percentages of total graft-derived GFP ${ }^{+}$cells found in each region, including striatum (STR), SCWM, LV, fimbria (FIM), RMS, OB, and hippocampus (HIP) at 1WAT. IgGab, Control anti-IgG antibody; EGFNab, EGF-neutralizing antibody. These percentages were obtained from counting the cells found in each region and the total cells found in each brain after grafting. Blue bars are cells derived from grafted NG2 ${ }^{+} / \mathrm{GFP}^{+}$cells treated with the anti-lgG antibody before transplantation, and red bars indicate cells derived from grafted NG2 ${ }^{+} / \mathrm{GFP}^{+}$treated with the EGFneutralizing antibody before transplantation. Data are shown as averages \pm SEM from three to four independent experiments. Unpaired $t$ test: STR, ${ }^{*} p<0.004 ;$ SCWM, ${ }^{*} p<0.0001 ; \mathrm{LV},{ }^{*} p<0.02 ; \mathrm{SVZ}{ }^{*} p<0.05 ; \mathrm{RMS},{ }^{*} p<0.02 ; \mathrm{FIM}{ }^{*} p<$ $0.01 ; 0 \mathrm{~B},{ }^{*} p<0.001 ; \mathrm{HIP},{ }^{*} p<0.005$.

migration in the postnatal brain (Aguirre and Gallo, 2004). This process occurs after RMS development is completed (Pencea and Luskin, 2003), indicating that dispersal of $\mathrm{NG}^{+}$cells is not attributable to simple diffusion within the ventricle and subsequent integration into accessible areas, but rather to active migration. Further- more, similar results were also obtained when grafting of $\mathrm{NG}_{2}{ }^{+}$cells was performed in older (P9-P10) host mice (Aguirre and Gallo, unpublished observation).

To define how EGFR may participate in this cell migration in vivo, we FACSpurified $\mathrm{NG}^{+} / \mathrm{GFP}^{+}$cells from $\mathrm{P} 8$ $\beta$-actin-GFP mice (Aguirre and Gallo, 2004) and preincubated them with the same EGF-neutralizing antibody used in our in vitro migration assays (Fig. $3 c, d$ ) to neutralize autocrine EGF signaling. Control cells were incubated with an anti-IgG control antibody. Both anti-EGF and antiIgG-treated cells were grafted into the LV of $\mathrm{P} 4 \mathrm{FVB} / \mathrm{NxCB} 6$ (wt) recipient mice. Figure 5, $a$ and $d$, shows results of experiments in which the migration pattern of anti-IgG-treated SVZ NG2 ${ }^{+} / \mathrm{GFP}^{+}$cells was analyzed 1 week after transplantation (1WAT). As demonstrated previously with cells not exposed to any antibody treatment (Aguirre and Gallo, 2004), most of the anti-IgG-treated cells migrated rostrally into the RMS and caudally to the SCWM, but a sizeable percentage was also found in the hippocampus (Fig. $5 b, d$ ). Conversely, when NG2 ${ }^{+}$cells were preincubated with the EGF-neutralizing antibody, the majority of grafted cells only displayed very limited migration and were found in the periventricular tissue (Fig. $5 c, d$ ). After exposure to the EGF-neutralizing antibody, migration of $\mathrm{NG}^{+} / \mathrm{GFP}^{+}$cells to the SCWM, OB, and hippocampus was severely reduced (Fig. $5 d$ ); instead, a significantly higher number of cells were found in the SVZ and in the fimbria and surrounding the wall of the LV (Fig. $5 c, d$ ). $\mathrm{NG}^{+} / \mathrm{GFP}^{+}$ cells that had not migrated were viable (i.e., TUNEL negative; data not shown) and appeared to be morphologically differentiated (Fig. $5 c$ ). These results suggest that the EGFR may play an important role in $\mathrm{NG}^{+}$cell migration from the SVZ into the RMS, OB, SCWM, and hippocampus.

\section{EGFR overexpression converts cortical $\mathrm{NG}{ }^{+}$cells from a nonmigratory to a migratory phenotype}

Our results demonstrate that cortical $\mathrm{NG}_{2}{ }^{+}$cells, differently from their SVZ counterpart, express low levels of EGFR and EGF and do not migrate in the presence of EGF (Figs. 1, 2). These results are consistent with previous grafting experiments in which cortical NG2 ${ }^{+}$cells isochronically transplanted into the LV displayed a very restricted migratory potential (Aguirre and Gallo, 2004).

To further define a causal relationship between EGFR expression and migratory potential of $\mathrm{NG} 2{ }^{+}$cells by using a different 

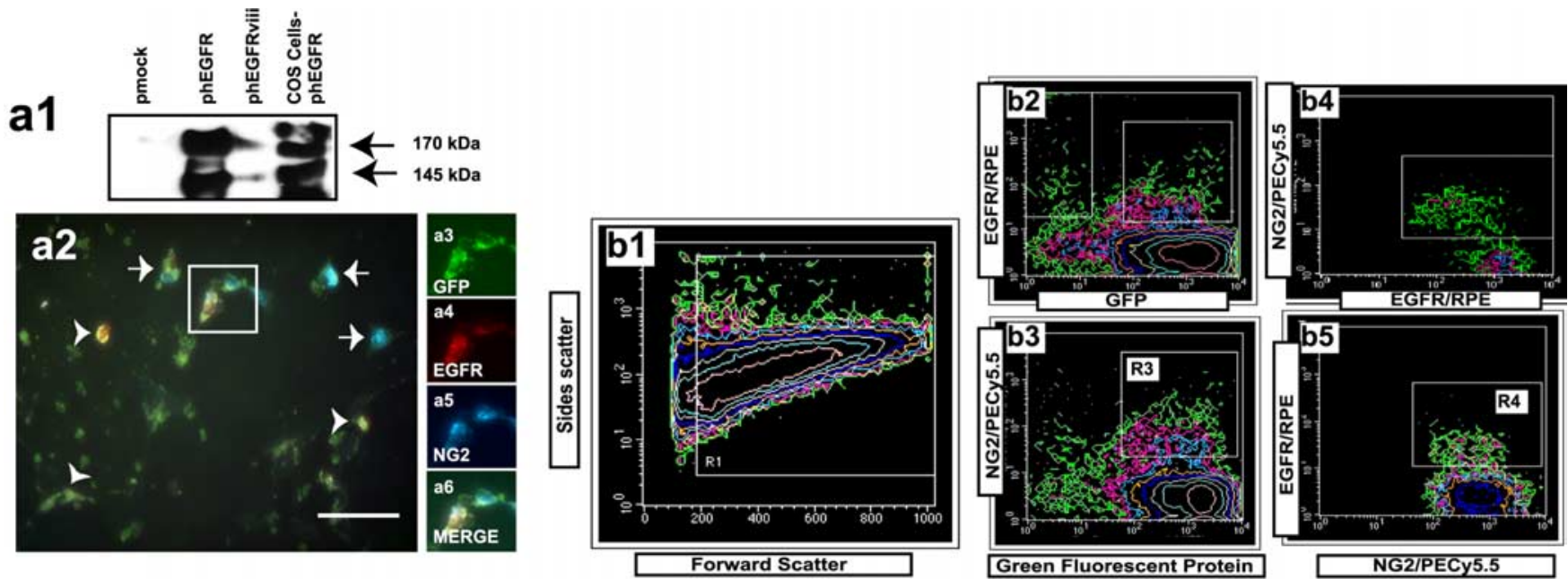
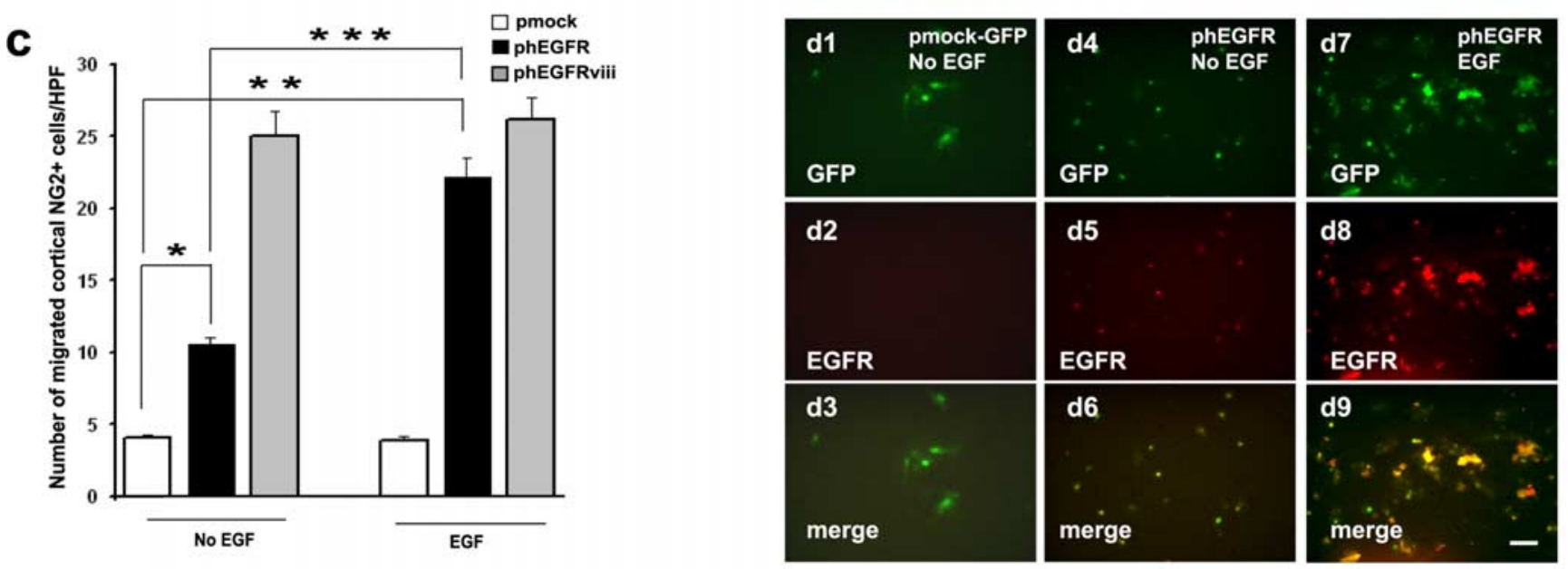

e

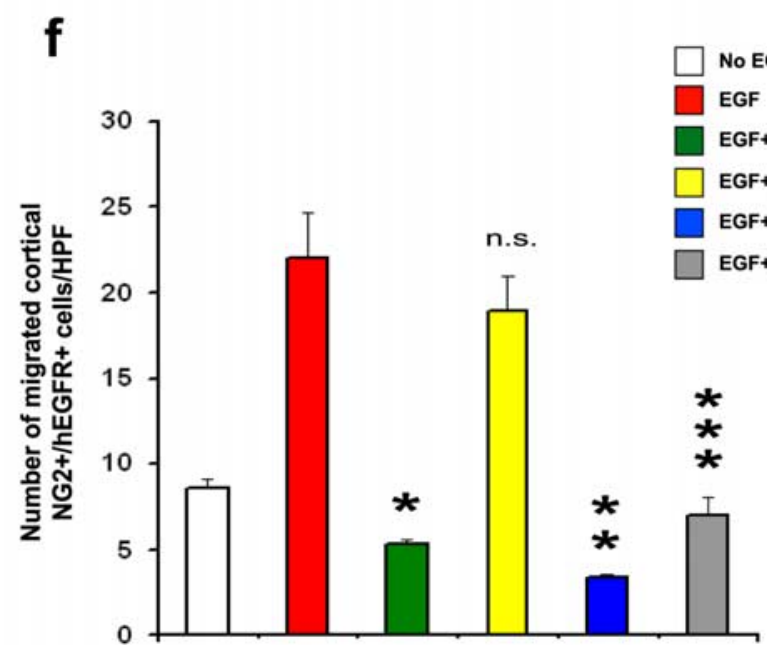

Figure 6. Overexpression of the hEGFR in nonmigratory cortical NG2 ${ }^{+}$cells promotes EGF-mediated migration in vitro. Cortical glial cultures were prepared from the cortex of Tg $\beta$-actin-GFP mice (P8) and were transfected with a wild-type hEGFR (phEGFR) or with a constitutively active EGFR construct (phEGFRviii). Cortical glial cultures were prepared from the cortex of FVB/NxCB6 mouse (P8) and were transfected with a pCMV-IRES-GFP (pmock) construct. $\boldsymbol{a}$, Construct expression in NG2 ${ }^{+}$cells. a1, Western blot of cortical cultures $36 \mathrm{~h}$ after transfection with the pmock, phEGFR, or phEGFRviii demonstrates expression of EGFR. Cos-pEGFR, Cos cells transfected with phEGFR. a2, Cortical cultures were immunolabeled $36 \mathrm{~h}$ after transfection with anti-hEGFR (red) and anti-NG2 (blue) antibodies. $\boldsymbol{b}$, Histograms of typical sorting profiles for NG2 ${ }^{+} / \mathrm{hEGFR}^{+} / \mathrm{GFP}^{+}$cells from cortical cultures transfected with the phEGFR construct. NG2 and hEGFR immunolabeling were scattered with PE-Cy5 (b2) and R-PE (b3), respectively. To scatter triple-positive (NG2 ${ }^{+} / \mathrm{hEGFR}^{+} / \mathrm{GFP}^{+}$) cells, the NG2 ${ }^{+} / \mathrm{GFP}^{+}$fraction (R3 box in b3) was double sorted using PE-Cy5.5 for NG2 and RPE for hEGFR (R4 box in $\boldsymbol{b 5}$ ). Note that a significant percentage of NG2 ${ }^{+} /$GFP ${ }^{+}$cells expressed the hEGFR. All data are shown as means \pm SEM obtained from a total of three to four separate experiments in triplicate. c, Transfected, FACS-purified cortical NG2 ${ }^{+} / \mathrm{mock}^{-G F P}{ }^{+}, \mathrm{NG}^{+} / \mathrm{hEGFR}^{+} / \mathrm{GFP}^{+}$, or NG2 ${ }^{+} / \mathrm{hEGFRviii}^{+} / \mathrm{GFP}^{+}$cells were used in migration assays in chemotaxis chambers. Cell migration was assayed $12 \mathrm{~h}$ after seeding the cells in microchemotaxis chambers. Overexpression of the hEGFR or hEGFRviii confers migratory properties to the cells. Note that, in 
approach, we first overexpressed the human EGFR (CMVhEGFR) or the constitutively active human EGFR (CMVhEGFRviii) (Schmidt et al., 1998) in cultured cortical glial cells prepared from P8 $\beta$-actin-GFP mice to FACS purify $\mathrm{NG}^{+}$/ $\mathrm{hEGFR}^{+} / \mathrm{GFP}^{+}$and NG2 ${ }^{+} / \mathrm{hEGFRviii}^{+} / \mathrm{GFP}^{+}$cells from these cultures. Figure $6 a$ shows Western blot analysis and immunostaining of cultured cortical $\beta$-actin-GFP ${ }^{+}$cells $36 \mathrm{~h}$ after transient transfection, before FACS purification. Western blot analysis demonstrated that transient transfection resulted in the expression of both the hEGFR and the hEGFRviii proteins, but higher levels of expression were observed with the hEGFR (Fig. 6a1). Expression of the hEGFR was undetectable in cortical cultures of wt mice transfected with a pCMV-IRES-GFP construct (Fig. 6a1, pmock). A significant percentage (9-10\%) of cortical $\mathrm{NG}_{2}{ }^{+}$cells present in the mixed glial cultures were transfected and expressed the hEGFR (Fig. 6a2-a6, arrows) or the hEGFRviii (data not shown) in the cell membrane, as demonstrated by immunostaining with anti-hEGFR antibodies.

We then FACS purified NG2 ${ }^{+} / \mathrm{hEGFR}^{+} / \mathrm{GFP}^{+}$and $\mathrm{NG}^{+} /$ hEGFRviii $^{+} / \mathrm{GFP}^{+}$cells (Fig. $6 b 1-b 5$ ) to perform in vitro and in vivo migration assays. Figure $6 c$ shows that expression of the hEGFR in purified cortical NG2 ${ }^{+} / \mathrm{GFP}^{+}$cells increased by approximately fourfold the migratory potential of these progenitors in the presence of EGF in vitro compared with mock-transfected cells. All of the $\mathrm{NG}^{+} / \mathrm{GFP}^{+}$cells that had migrated in the presence of EGF were hEGFR ${ }^{+}$(Fig. $6 d 4-d 9$ ). The increased migratory potential of cortical NG2 ${ }^{+}$cells transfected with the hEGFR was confirmed by overexpression of the hEGFRviii. Figure $6 c$ shows that FACS-purified cortical $\mathrm{NG}^{+} / \mathrm{hEGFRviii}^{+} / \mathrm{GFP}^{+}$ cells displayed a higher migration than mock-transfected cells, in both the absence and presence of EGF. As demonstrated for SVZ $\mathrm{NG}^{+}$cells (Fig. $3 a$ ), the presence of EGF in both the lower and upper chambers prevented cell migration also in cortical NG2 ${ }^{+}$/ hEGFR $^{+} / \mathrm{GFP}^{+}$cells (Fig. $6 e$ ). Under these conditions, $\mathrm{NG}^{+} /$ $\mathrm{hEGFR}^{+} / \mathrm{GFP}^{+}$cell migration was $\sim 50 \%$ of that observed in the absence of EGF, indicating that overexpression of the hEGFR by itself promotes migration of cortical NG2 ${ }^{+}$cells. Finally, both the EGFR inhibitor PD168393 and the neutralizing antibodies for EGFR and EGF prevented migration of cortical $\mathrm{NG}^{+} / \mathrm{GFP}^{+} /$ hEGFR ${ }^{+}$cells (Fig. $6 f$ ).

To demonstrate that cortical NG $2^{+} / \mathrm{GFP}^{+} / \mathrm{hEGFR}^{+}$cells also migrate in vivo, we grafted these transfected cells into the LV of $\mathrm{P} 4$ wt mice. Mock-transfected $\mathrm{NG}^{+} / \mathrm{GFP}^{+}$cells did not migrate and were found mostly surrounding the wall of the LV, the SVZ, and the fimbria (Fig. $7 a, b, i)$. Conversely, $\mathrm{NG}^{+} / \mathrm{GFP}^{+} / \mathrm{hEGFR}^{+}$ cells displayed extensive rostral and caudal migration (Fig. $7 c-$ $f, i)$. At $1 \mathrm{WAT}$, a large percentage of graft-derived $\mathrm{NG}^{+} / \mathrm{GFP}^{+} /$ $\mathrm{hEGFR}^{+}$cells were found in the SCWM, RMS, OB, and hippocampus (Fig. $7 c-f, i$ ). These cells continued to express the hEGFR at 1WAT, as demonstrated by immunostaining with a selective anti-hEGFR antibody (Fig. $7 h 1-h 4$, example of cells in SCWM).

\section{$\mathrm{NG}^{+}{ }^{+}$cells from the cerebral cortex of the CNP-hEGFR-} overexpressing mouse display a migratory phenotype

To further investigate the role of the EGFR in NG2 ${ }^{+}$cell migration, we used a transgenic mouse in which the hEGFR was expressed in multipotential progenitors and in cells of the oligodendrocyte lineage under the control of the CNP promoter (CNP-hEGFR mouse) (Ling et al., 2005). We first analyzed expression of the hEGFR in cortical NG2 ${ }^{+}$cells of this mouse at P8. Only cortical NG2 ${ }^{+}$cells from the CNP-hEGFR mouse expressed high levels of the hEGFR, whereas the same cell population from a C57B6 (wt) mouse did not (Aguirre and Gallo, unpublished observation).

To obtain additional direct evidence that EGFRs are involved in $\mathrm{NG}_{2}{ }^{+}$cell migration in vivo, we FACS purified cortical NG2 ${ }^{+}$ cells from the CNP-hEGFR mouse, in which all NG2 ${ }^{+}$cells constitutively expressed the hEGFR. When FACS-purified P8 $\mathrm{NG}^{+}{ }^{+}$CNP-hEGFR ${ }^{+}$cells were transplanted into the LV of P4 wt mouse brains, they displayed extensive rostral and caudal migration at 1WAT (Fig. 8). Importantly, the migration pattern and distribution of the grafted cells was very similar to that observed with wt SVZ NG2 ${ }^{+}$cells (Aguirre and Gallo, 2004) (Fig. 5) or with $\mathrm{NG}^{+} / \mathrm{hEGFR}^{+} / \mathrm{GFP}^{+}$cells (Fig. 7 ). Also, $\mathrm{NG}^{+} / \mathrm{CNP}-$ hEGFR $^{+}$cortical cells migrated to the SCWM (Fig. $8 a$ ), through the RMS into the OB (Fig. 8a), and to the hippocampus (Fig. $8 c, d)$. The majority of graft-derived cells migrating through the RMS were still NG2 ${ }^{+}$(Fig. 8b) (Aguirre and Gallo, 2004), indicating that the original progenitor phenotype was maintained in grafted $\mathrm{NG}^{+}{ }^{+}$cells overexpressing the hEGFR. In parallel grafting experiments, it was confirmed that, as demonstrated previously in an independent study (Aguirre and Gallo, 2004), grafted wt cortical NG2 ${ }^{+}$cells displayed very limited migration (Fig. 8e) (supplemental Fig. S3, available at www.jneurosci.org as supplemental material).

To define the differentiation potential of cortical $\mathrm{NG}^{+} /$ $\mathrm{hEGFR}^{+}$cells, we FACS purified cortical NG $2{ }^{+} / \mathrm{CNP}^{-\mathrm{hEGFR}^{+}}$/ $\mathrm{GFP}^{+}$cells from a P8 CNP-hEGFR/Tg ActbGFP mouse and grafted these cells using the same transplantation paradigm used in the experiment shown in Figure 8 . These GFP ${ }^{+}$cells displayed the same migration pattern shown for $\mathrm{NG}^{+} / \mathrm{CNP}^{-} \mathrm{hEGFR}^{+}$ cells (Fig. 8) and maintained NG2 expression while they were migrating throughout the RMS (Fig. 9a). Analysis with a variety of cell markers demonstrated that, in all of these regions, the vast majority of graft-derived CNP-hEGFR ${ }^{+} / \mathrm{GFP}^{+}$cells at $1 \mathrm{WAT}$ were $\mathrm{GFAP}^{+}$astrocytes (Fig. 9c) or $\mathrm{CNP}^{+}$oligodendrocytes (Fig. $9 d)$. Interestingly, the percentage of astrocytes generated in the SCWM after transplantation of cortical NG2 ${ }^{+} / \mathrm{CNP}^{-\mathrm{hEGFR}^{+}} /$ $\mathrm{GFP}^{+}$cells was significantly higher than with wt cells, whereas the percentage of oligodendrocytes was lower (Fig. 9b).

Analysis of the graft-derived CNP-hEGFR ${ }^{+}$and wt $\mathrm{GFP}^{+}$ cells demonstrated that their proliferation rate was similar [percentage of $\mathrm{Ki}-67^{+}$cells, $11.0 \pm 2.4 \%$ for wt $(n=223)$ and $13.6 \pm 3.5$ for CNP-hEGFR ${ }^{+}(n=285)$ cells, respectively]. Im- 
portantly, when grafted brains were analyzed 3 months after transplantation of $\mathrm{NG}^{+} / \mathrm{CNP} \mathrm{hEGFR}^{+} / \mathrm{GFP}^{+}$cells, no evidence for tumor formation was found, as determined by hematoxylin and eosin staining (Aguirre and Gallo, unpublished observation).

\section{Discussion}

The identification of cellular and molecular signals that promote proliferation, migration, and survival of postnatal neural progenitors is a priority in designing approaches for cell transplantation-based therapies (Bjorklund and Lindvall, 2000; Lindvall et al., 2004). The present study shows that multipotential NG2 ${ }^{+}$progenitor cells offer a unique opportunity to devise cell transplantation strategies in the CNS, because these cells are found in different areas of the brain, in which they display distinct migratory and lineage potentials. By combining in vitro and in vivo studies, we demonstrate that endogenous EGFR expression is causally related to the different migratory potential that $\mathrm{NG}_{2}{ }^{+}$ progenitor cells display in distinct brain regions. We also show that enhancing EGFR expression in nonmigratory $\mathrm{NG}^{+}$ cells that otherwise express lower levels of this receptor causes a conversion to a migratory phenotype and promotes their dispersal into different regions of the brain after transplantation.

Previous studies have demonstrated that neural progenitor cells from the postnatal/adult SVZ can migrate to different brain regions, i.e., rostrally through the RMS to the OB (Law et al., 1999; Alvarez-Buylla et al., 2000), and radially/caudally to the SCWM (Kakita and Goldman, 1999; Suzuki and Goldman, 2003). Under pathological conditions, SVZ progenitors display additional migration patterns. In the ischemia brain injury model, after exogenous EGF and FGF-2 application, Mash ${ }^{+}$multipotential neural progenitors migrate from the SVZ to the hippocampus, in which they terminally differentiate to interneurons (Nakatomi et al., 2002). NG2 ${ }^{+}$progenitor cells in the early postnatal SVZ are highly proliferative and express cellular properties that correspond to the adult type C cells, including Mash1 (Aguirre et al., 2004). When these cells were transplanted into the LV, they migrated rostrally and caudally to the OB and SCWM, respectively, but also to the hippocampus, in which they generated inhibitory interneurons (Aguirre and Gallo, 2004; Aguirre et al.,
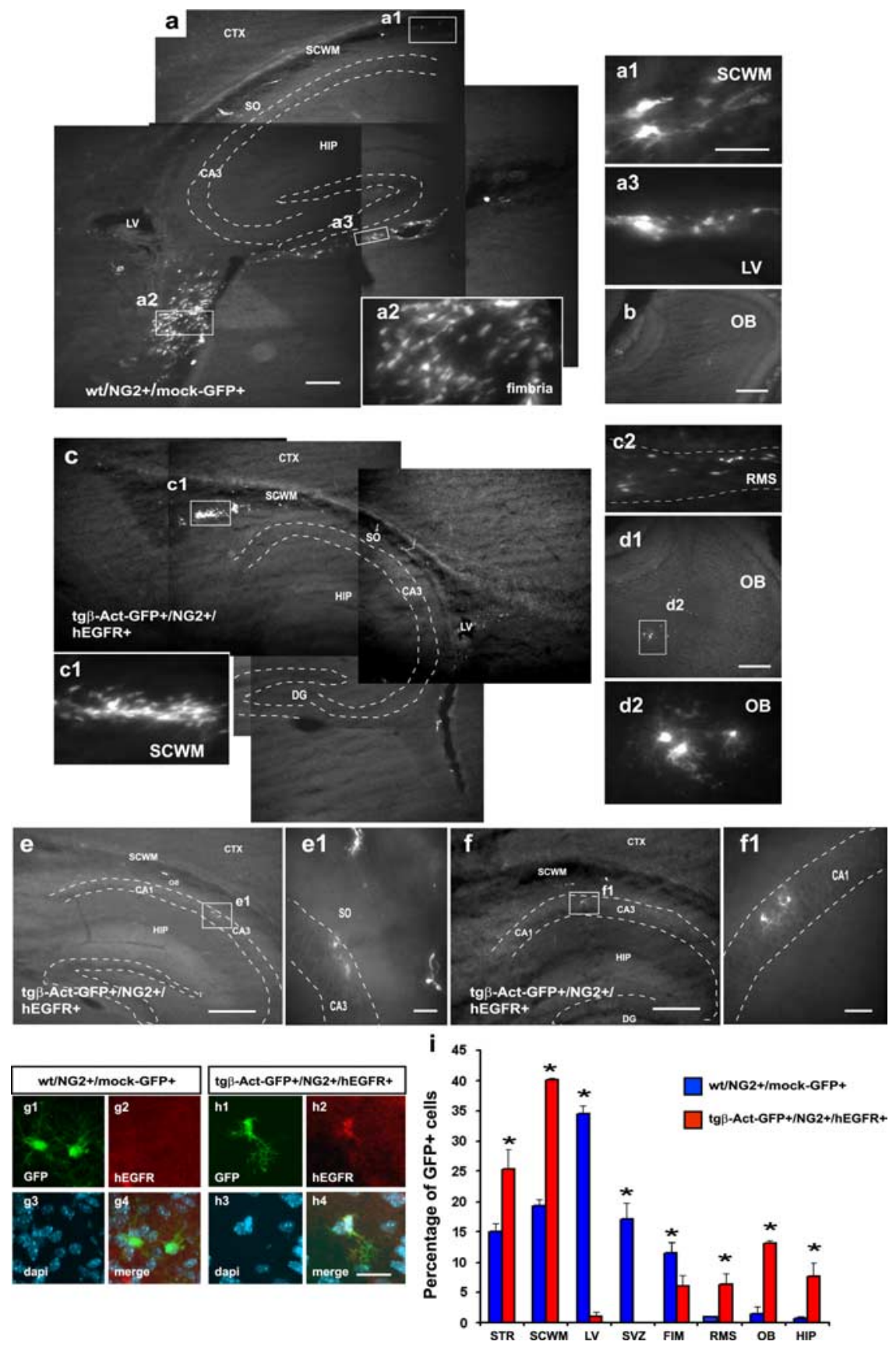

Figure 7. Overexpression of the hEGFR in nonmigratory cortical NG2 ${ }^{+}$cells promotes EGF-mediated migration in vivo. $\boldsymbol{a}$, Cortical glial cultures from wt P8 FVB/NxCB6 mouse were transfected with a pCMV-IRES-GFP (mock-GFP), and NG2 ${ }^{+} /$GFP $^{+}$cells were FACS purified. FACS-purified wt/NG2 ${ }^{+} /$mock-GFP $^{+}$cells were transplanted in the LV of P4 wt host mice. Brains were analyzed at 1 WAT. Graft-derived wt/mock-GFP ${ }^{+}$cells were visualized by fluorescence microscopy after anti-GFP immunostaining. Cortical wt/mock-GFP ${ }^{+}$cells displayed very restricted migration, with a small percentage of graft-derived cells found in the SCWM (a1). The majority of the graft-derived wt/mock-GFP ${ }^{+}$cells were found in the parenchyma, in the fimbria (a2), and in the ependymal layer of the LV $(\boldsymbol{a} 3)$. $\boldsymbol{b}$, No cells were observed in the OB. c, Cortical glial cultures from Tg $\beta$-actin-GFP mice were transfected with a wild-type hEGFR (phEGFR), and $\mathrm{Tg} \beta$-actin-GFP ${ }^{+} / \mathrm{NG2}{ }^{+} / \mathrm{hEGFR}^{+}$cells were FACS purified and transplanted into the LV as described in $\boldsymbol{a}$. Brains were analyzed 1WAT. Graft-derived hEGFR ${ }^{+} / \mathrm{GFP}^{+}$cells were found in the RMS (c2) and in the $\mathrm{OB}(\boldsymbol{d} \mathbf{1}) . \mathrm{hEGFR}^{+} / \mathrm{GFP}^{+}$cells were also found in the SCWM (c1) and in the hippocampus $(\boldsymbol{e}, \boldsymbol{f}) \cdot \boldsymbol{g}, \boldsymbol{h}$, Immunostaining with a selective anti-hEGFR antibody shows that graft-derived $\mathrm{Tg} \beta$-actin-GFP ${ }^{+} / \mathrm{hEGFR}^{+}$cells in SCWM (h1- $\left.\boldsymbol{h} 4\right)$, but not wt/mock$\mathrm{GFP}^{+}$cells in the same brain region $(\boldsymbol{g} \mathbf{1}-\boldsymbol{g} 4)$, express the hEGFR at 1WAT. $\boldsymbol{i}$, Histograms represent percentages of total graftderived cells found in each region, including striatum (STR), SCWM, fimbria (FIM), LV, SVZ, RMS, OB, and hippocampus (HIP) at 1WAT. These percentages were obtained from counting the cells found in each region and the total cells found in each brain after grafting. Blue bars are cells derived from grafted wt/NG2 ${ }^{+} /$mock-GFP ${ }^{+}$cells, and red bars indicate cells derived from grafted $\operatorname{Tg} \beta$-actin-GFP ${ }^{+} / \mathrm{NG}^{+} / \mathrm{hEGFR}^{+}$cells. Dotted lines depict the hippocampus $(\boldsymbol{a}-\boldsymbol{e})$. Scale bars: $\boldsymbol{a}, \boldsymbol{b}, \boldsymbol{c}, \boldsymbol{d} \mathbf{1}, \boldsymbol{e}, \boldsymbol{f}$, $300 \mu \mathrm{m} ; \boldsymbol{a} \mathbf{1}-\boldsymbol{a} \mathbf{3}, \mathbf{c} \mathbf{1}, \mathbf{c 2}, \boldsymbol{d} \mathbf{2}, \boldsymbol{e} \mathbf{1}, \boldsymbol{f 1}, \boldsymbol{g} \mathbf{1}-\boldsymbol{g} \mathbf{4}, \boldsymbol{h} \mathbf{1}-\boldsymbol{h} \mathbf{4}, 50 \mu \mathrm{m}$. Data are shown as means \pm SEM from three independent experiments. Unpaired $t$ test: STR, ${ }^{*} p<0.01 ;$ SCWM, ${ }^{*} p<0.0004 ; \mathrm{LV},{ }^{*} p<0.0001 ; \mathrm{SVZ},{ }^{*} p<0.008$; FIM, ${ }^{*} p<0.01$; RMS, ${ }^{*} p<0.02 ; 0 \mathrm{~B},{ }^{*} p<0.006 ; \mathrm{HIP},{ }^{*} p<0.01$. 

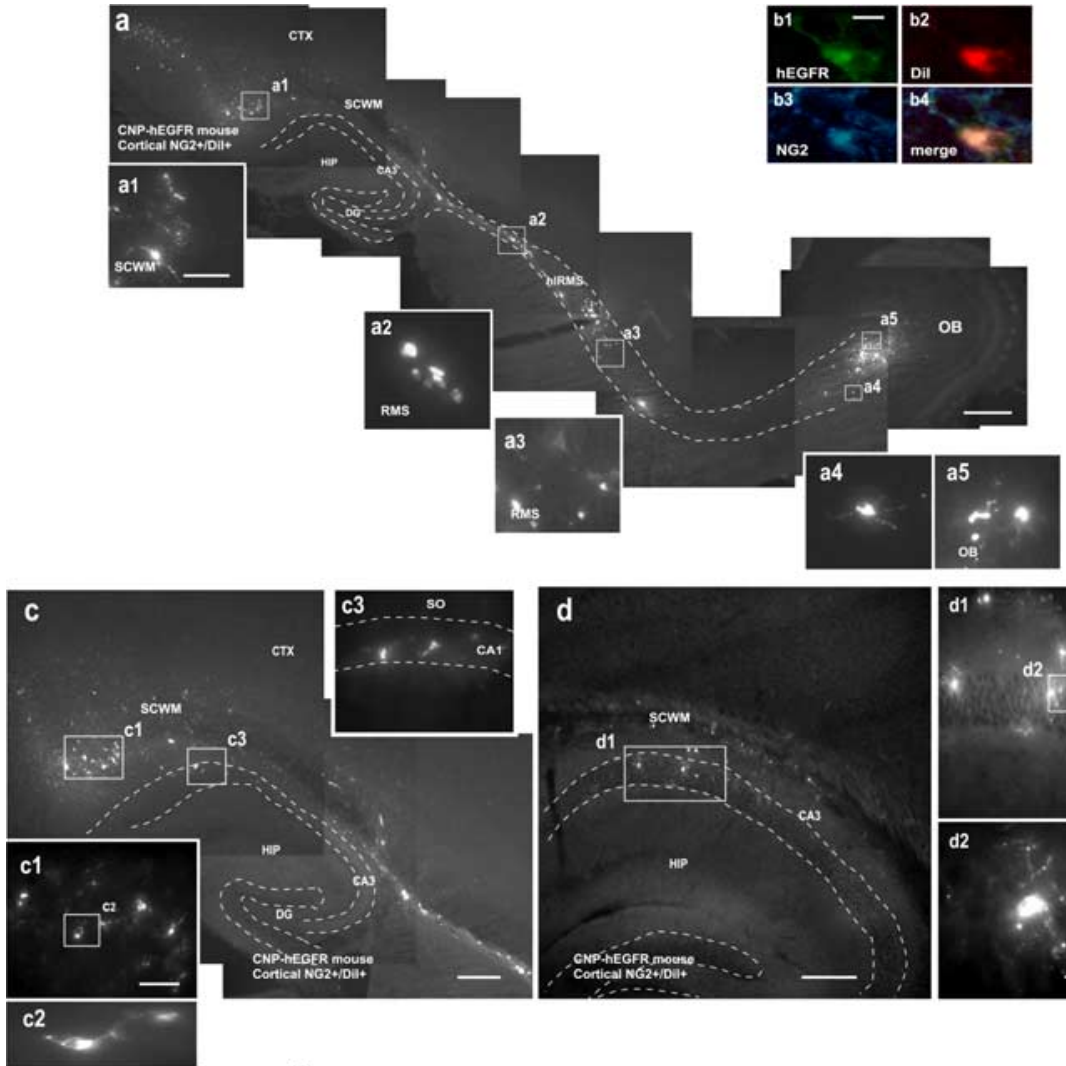

Cortical NG2+10it:

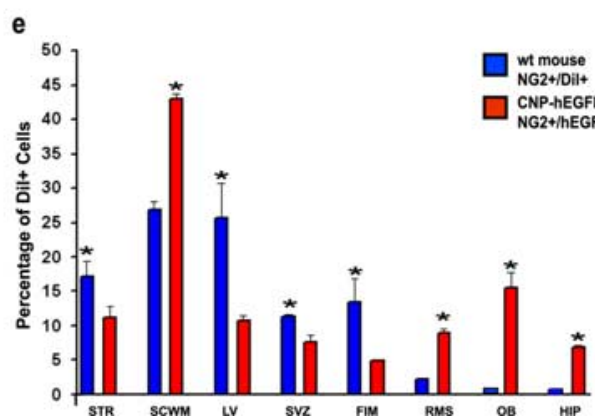

Figure 8. Cortical NG2 ${ }^{+} / \mathrm{hEGFR}^{+}$cells from the CNP-hEGFR mouse display extensive rostral and caudal migration after grafting. NG2 ${ }^{+}$cells were FACS purified from the cerebral cortex of P8 CNP-hEGFR mice and stained with Dil before transplantation into the LV of P4 wt host mice. $a$, Grafted NG2 ${ }^{+} / \mathrm{hEGFR}^{+} / \mathrm{Dil}{ }^{+}$cells displayed extensive rostral and caudal migration 1WAT. Graft-derived cells were observed throughout the entire $\operatorname{SCWM}(\boldsymbol{a} 1)$, $\operatorname{RMS}(\boldsymbol{a} \mathbf{2}, \boldsymbol{a} 3)$, and into the $\mathrm{OB}(\boldsymbol{a} 4, \boldsymbol{a} 5) . \boldsymbol{b}$, Graft-derived $\mathrm{hEGFR}^{+} / \mathrm{Dil}^{+}$cells were still NG2 ${ }^{+}$and were immunostained with a selective anti-hEGFR antibody 1WAT. $\boldsymbol{c}, \boldsymbol{d}$, Graft-derived $\mathrm{hEGFR}^{+} / \mathrm{Dil}^{+}$cells were also found in the hippocampus. Dotted lines depict the RMS $(\boldsymbol{a})$ and hippocampus $(\boldsymbol{c}, \boldsymbol{d})$. Highmagnification images obtained from the boxed areas are shown in $\boldsymbol{a 1} \mathbf{1} \boldsymbol{a} \mathbf{5}, \boldsymbol{c} \mathbf{1}-\mathbf{c} \mathbf{3}, \boldsymbol{d 1}$, and $\boldsymbol{d} \mathbf{2}$. $\boldsymbol{e}$, Histograms represent percentages of graft-derived cells found in each region, including striatum (STR), SCWM, fimbria (FIM), LV, SVZ, RMS, OB, and hippocampus (HIP) at 1WAT. These percentages were obtained from counting the cells found in each region and the total cells found in each brain after grafting. Blue bars are cells derived from grafted wt NG2 ${ }^{+} / \mathrm{Dil}^{+}$cells, and red bars indicate cells derived from grafted $\mathrm{NG2}^{+} / \mathrm{hEGFR}^{+} / \mathrm{Dil}^{+}$cells. Scale bars: $\boldsymbol{a}, \boldsymbol{c}, \boldsymbol{d}, 300 \mu \mathrm{m} ; \boldsymbol{a} \mathbf{1}-\boldsymbol{a} \mathbf{5}, \boldsymbol{b} \mathbf{1}-\boldsymbol{b} \mathbf{b}, \boldsymbol{c} \mathbf{1 - c} \mathbf{c}, \boldsymbol{d} \mathbf{1}, \boldsymbol{d 2}, 50 \mu \mathrm{m}$. Unpaired $t$ test, comparing EGFR-transfected versus mock-transfected cells: STR, ${ }^{*} p<0.05 ; \mathrm{SCWM}^{*}{ }^{*} p<0.01 ; \mathrm{LV},{ }^{*} p<0.02 ; \mathrm{SVZ}^{*}{ }^{*} p<0.003 ; \mathrm{FIM},{ }^{*} p<$ $0.04 ; \mathrm{RMS}^{*}{ }^{*} p<0.009 ; 0 \mathrm{~B},{ }^{*} p<0.004 ; \mathrm{HIP},{ }^{*} p<0.003$.

2004). Altogether, these results indicate that different SVZ progenitors are likely to use distinct endogenous migratory routes under physiological or pathological conditions.

EGF and EGFRs are expressed in the SVZ, RMS, and hippocampus (Seroogy et al., 1995; Anton et al., 2004; Fox and Kornblum, 2005). EGF is the best characterized mitogen for SVZ neural progenitor cells (Kuhn et al., 1997; Doetsch et al., 1999, 2002; Gritti et al., 1999). Intraventricular injection of EGF into the adult SVZ promotes progenitor proliferation as well as migration out of the lateral wall (Craig et al., 1996), indicating that EGF and EGFRs may play a dual role in SVZ progenitor development. Our

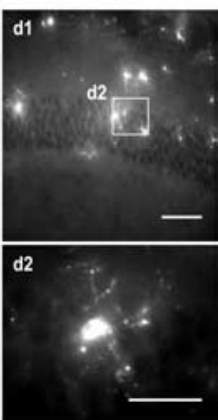

results indicate that both EGFRs and EGF are expressed at higher levels in $\mathrm{NG}^{+}$ progenitor cells of the SVZ than in cortical $\mathrm{NG}^{+}{ }^{+}$cells, indicating that autocrine activation of EGFRs is likely to occur in SVZ $\mathrm{NG}^{+}$cells (Junier, 2000). In the rodent brain, mobilization and migration of SVZ progenitors into the SCWM is still occurring during the first postnatal week (LeVine and Goldman, 1988; Marshall and Goldman, 2002; Kakita et al., 2003; Zerlin et al., 2004). Therefore, the finding that EGFRs and EGF are highly expressed in $\mathrm{NG}_{2}{ }^{+}$cells that display a migratory phenotype are consistent with the idea that EGFRs could regulate migration of these cells out of the postnatal SVZ.

In the present study, we demonstrate marked differences in the migratory potential of SVZ versus cortical NG2 ${ }^{+}$cells and a functional role for EGFRs in SVZ $\mathrm{NG}_{2}{ }^{+}$cell migration. EGF stimulates SVZ $\mathrm{NG} 2{ }^{+}$cell migration by a concentrationdependent gradient mechanism but is ineffective on cortical cells. Inhibition of EGFR activation by using either a receptor blocker or an EGF-neutralizing antibody prevents migration of SVZ $\mathrm{NG}^{+}$cells. Finally, EGF-induced migration of NG2 ${ }^{+}$ cells is likely to involve integrin-ECM protein interactions (Lin and Bertics, 1995; Hintermann et al., 2001) because (1) it only occurs in the presence of laminin, fibronectin, or vitronectin and (2) is prevented by a peptide inhibitor of the integrin-ECM binding site. These results are consistent with previous findings showing that interactions between EGF and integrin signaling play an important role in supporting cell migration (Lin and Bertics, 1995; Moro et al., 1998; Xie et al., 1998).

Previous studies revealed a role for the EGFR in radial neural progenitor migration in the developing telencephalon (Burrows et al., 1997; Caric et al., 2001; Ciccolini et al., 2005). To demonstrate a function for EGFRs in SVZ tangential and radial/caudal migration in vivo, we used a previously established transplantation paradigm of early postnatal $\mathrm{NG}^{+}$cells FACS purified from the SVZ and the cerebral cortex. Grafted SVZ NG2 ${ }^{+}$progenitor cells migrate extensively into the postnatal RMS, OB, SCWM, and hippocampus, whereas cortical NG2 ${ }^{+}$cells display very restricted migration (Aguirre and Gallo, 2004). Here we show that SVZ NG2 ${ }^{+}$progenitor cells preincubated with EGF signalingneutralizing antibodies before transplantation did not migrate out of the wall of the LV and the fimbria.

In additional support of a role of EGFR in promoting migration of $\mathrm{NG}^{+}$cells, we overexpressed the hEGFR in nonmigratory cortical NG2 ${ }^{+}$cells and found that cortical NG2 ${ }^{+} / \mathrm{hEGFR}^{+}$ cells migrate in the presence of EGF in vitro. This process is (1) dependent on an EGF concentration gradient, (2) ECM/integrin- 
dependent, and (3) prevented by blockage of the EGFR. We then used two different approaches to demonstrate that enhancement of EGFR expression increased the migratory potential of cortical NG2 ${ }^{+}$cells in vivo. First, we transplanted transfected cortical $\mathrm{NG}^{+} / \mathrm{hEGFR}^{+}$cells into the early postnatal LV, and, second, we grafted cortical NG2 ${ }^{+}$cells FACS purified from a transgenic mouse overexpressing the hEGFR under the CNP promoter (Ling et al., 2005). Previous analysis from our laboratory demonstrated that all $\mathrm{NG} 2{ }^{+}$cells express the CNP gene (Yuan et al., 2002; Aguirre et al., 2004; Chittajallu et al., 2004). Both approaches used in the present study gave very similar results, i.e., a few days after transplantation, graftderived cortical cells were found in the SCWM and hippocampus and in numbers similar to those observed after transplantation of SVZ NG $2{ }^{+}$cells. Furthermore, as demonstrated previously with SVZ NG2 ${ }^{+}$ cells (Aguirre and Gallo, 2004), a large percentage of graft-derived cells were also found migrating through the RMS into the OB. The increased percentages of cells found in these regions was not attributable to an increased rate of cell proliferation of the grafted $\mathrm{NG} 2{ }^{+} / \mathrm{hEGFR}^{+}$cells, as demonstrated by (1) similar anti-Ki-67 staining in graft-derived control and hEGFR ${ }^{+}$ cells, and (2) the finding that increased percentages of graft-derived $\mathrm{hEGFR}^{+}$ cells in specific brain regions (i.e., OB, RMS, SCWM, and hippocampus) consistently corresponded to a proportional decrease in those regions from which these cells were migrating (i.e., SVZ, fimbria, and lateral wall). These results are consistent with the interpretation that, in our experimental model, EGFRs are necessary for $\mathrm{NG}_{2}{ }^{+}$cell migration in the postnatal brain. It appears that unique interactions between cellular EGFRs and the tissue environment play a crucial role in directing NG2 ${ }^{+}$cell migration to different brain regions.

Cortical NG2 ${ }^{+}$cells can generate neurons, oligodendrocytes, and astrocytes in vitro (Chittajallu et al., 2004), and a small percentage of cortical NG2 ${ }^{+}$cells express $\mathrm{NeuN}$ and other neuronal markers in situ (Dayer et al., 2005). In the present study, analysis of graft-derived cells demonstrated that, although cortical $\mathrm{NG}^{+}{ }^{+} / \mathrm{CNP}-\mathrm{hEGFR}^{+}$cells migrate similarly to wild-type SVZ $\mathrm{NG}_{2}{ }^{+}$cells (Aguirre and Gallo, 2004), they only generate astrocytes and oligodendrocytes in OB, SCWM, and hippocampus but do not generate neurons. This finding is consistent with previous studies showing that overexpression of the EGFR promotes a gliogenic fate in neural progenitor cells (Burrows et al., 1997, 2000; Caric et al., 2001; Sun et al., 2005).

EGFR overexpression in SVZ progenitor cells might cause brain tumors, which may derive from brain progenitor/stem cells (for review, see Fomchenko and Holland, 2005). Oligodendrogliomas, which constitute $20 \%$ of glial tumors, and astrocytomas are correlated with increased EGFR signaling. In oligodendrogliomas, EGFR is frequently expressed at high levels; in astrocytomas, EGFR expression is associated with high-grade tumors and is associated with EGFR amplification or mutation (Libermann
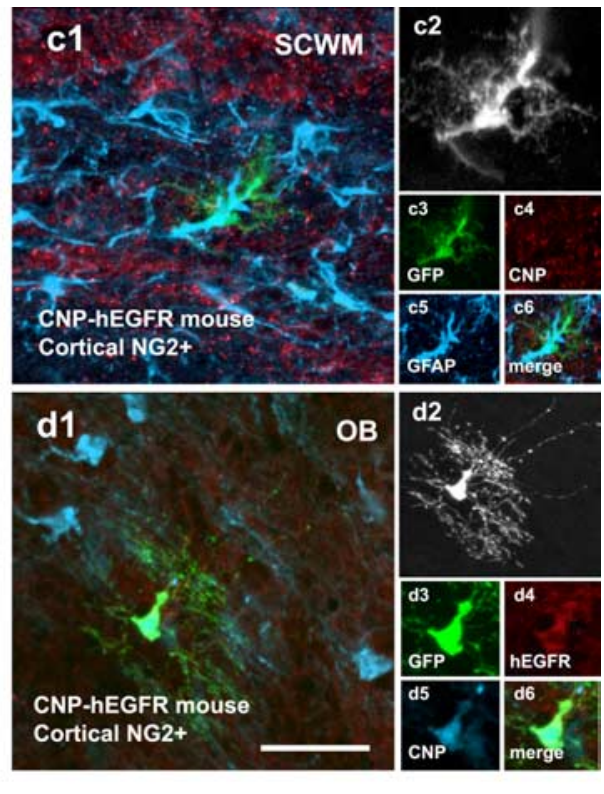

Figure 9. Cortical NG2 ${ }^{+} / \mathrm{hEGFR}^{+}$cells from the CNP-hEGFR mouse generate astrocytes and oligodendrocytes in the white matter after grafting. FACS-purified cortical NG2 ${ }^{+} /$CNP-hEGFR $^{+} /$GFP $^{+}$cells from a P8 CNP-hEGFR/Tg ActbGFP mouse were

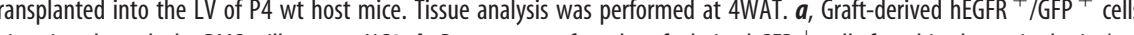

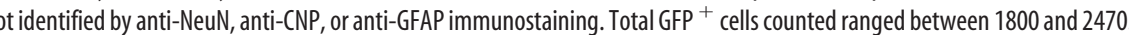

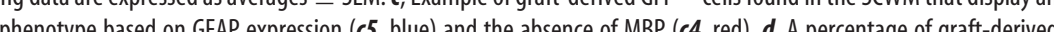
$\mathrm{hEGFR}^{+} / \mathrm{GFP}^{+}$cells found in the $0 \mathrm{~B}$ display a differentiated oligodendrocyte $(0 \mathrm{~L})$ phenotype based on the expression of CNP ( $\mathbf{d 6}$, blue). Scale bars: $\boldsymbol{b}, 20 \mu \mathrm{m} ; \boldsymbol{a}, \boldsymbol{c}, \boldsymbol{d}, 50 \mu \mathrm{m}$.

et al., 1985; Wong et al., 1992; Smith et al., 2001). When modeled in mice, only $v$-erb, a constitutively active allele, is transforming, whereas EGFR is transforming only in the presence of ligand (Nishikawa et al., 1994; Holland et al., 1998; Weiss et al., 2003). In our model, a wild-type EGFR allele unlikely to cause transformation is expressed, and ligand availability should determine when and where the receptor is activated (Ling et al., 2005). Supporting the lack of transformation by the wild-type EGFR allele, when we aged a cohort of 30 CNP-hEGFR mice, none developed brain tumors, and mice died with the same kinetics as wild-type mice (Ling et al., 2005). Furthermore, we did not observe tumor formation in host mouse brains up to 3-4 months after grafting NG2 ${ }^{+} / \mathrm{CNP}-\mathrm{hEGFR}^{+}$cells.

In conclusion, our findings indicate that EGFR expression plays an important role in promoting migration of SVZ neural progenitors and that manipulation of EGFR expression can convert neural progenitors from a nonmigratory to a migratory phenotype in the postnatal brain. Our studies will not only help understanding how intrinsic properties and specific cellular environments cooperate to promote cell migration and differentiation, but will also lead to optimizing the use of neural progenitors for therapeutic approaches in the damaged brain.

\section{References}

Aguirre A, Gallo V (2004) Postnatal neurogenesis and gliogenesis in the olfactory bulb from NG2-expressing progenitors of the subventricular zone. J Neurosci 24:10530-10541.

Aguirre AA, Chittajallu R, Belachew S, Gallo V (2004) NG2-expressing cells in the subventricular zone are type C-like cells and contribute to interneuron generation in the postnatal hippocampus. J Cell Biol 165:575-589. 
Alvarez-Buylla A, Herrera DG, Wichterle H (2000) The subventricular zone: source of neuronal precursors for brain repair. Prog Brain Res $127: 1-11$.

Anton ES, Ghashghaei HT, Weber JL, McCann C, Fischer TM, Cheung ID, Gassmann M, Messing A, Klein R, Schwab MH, Lloyd KC, Lai C (2004) Receptor tyrosine kinase ErbB4 modulates neuroblast migration and placement in the adult forebrain. Nat Neurosci 7:1319-1328.

Bagri A, Marin O, Plump AS, Mak J, Pleasure SJ, Rubenstein JL, TessierLavigne M (2002) Slit proteins prevent midline crossing and determine the dorsoventral position of major axonal pathways in the mammalian forebrain. Neuron 33:233-248.

Belachew S, Chittajallu R, Aguirre AA, Yuan X, Kirby M, Anderson S, Gallo V (2002) Postnatal NG2 proteoglycan-expressing progenitor cells are intrinsically multipotent and generate functional neurons. J Cell Biol 161:169-186

Bjorklund A, Lindvall O (2000) Cell replacement therapies for central nervous system disorders. Nat Neurosci 3:537-544.

Buckley CD, Pilling D, Henriquez NV, Parsonage G, Threlfall K, ScheelToellner D, Simmons DL, Akbar AN, Lord JM, Salmon M (1999) RGD peptides induce apoptosis by direct caspase-3 activation. Nature 397:534-539.

Burrows RC, Wancio D, Levitt P, Lillien L (1997) Response diversity and the timing of progenitor cell maturation are regulated by developmental changes in EGFR expression in the cortex. Neuron 19:251-267.

Burrows RC, Lillien L, Levitt P (2000) Mechanisms of progenitor maturation are conserved in the striatum and cortex. Dev Neurosci 22:7-15.

Caric D, Raphael H, Viti J, Feathers A, Wancio D, Lillien L (2001) EGFRs mediate chemotactic migration in the developing telencephalon. Development 128:4203-4216.

Chittajallu R, Aguirre A, Gallo V (2004) NG2-positive cells in the mouse white and grey matter display distinct physiological properties. J Physiol (Lond) 561:109-122.

Ciccolini F, Mandl C, Holzl-Wenig G, Kehlenbach A, Hellwig A (2005) Prospective isolation of late development multipotent precursors whose migration is promoted by EGFR. Dev Biol 284:112-125.

Conover JC, Doetsch F, Garcia-Verdugo JM, Gale NW, Yancopoulos GD, Alvarez-Buylla A (2000) Disruption of Eph/ephrin signaling affects migration and proliferation in the adult subventricular zone. Nat Neurosci 11:1091-1097.

Corfas G, Roy K, Buxbaum JD (2004) Neuregulin 1-erbB signaling and the molecular/cellular basis of schizophrenia. Nat Neurosci 7:575-580.

Craig CG, Tropepe V, Morshead CM, Reynolds BA, Weiss S, van der Kooy D (1996) In vivo growth factor expansion of endogenous subependymal neural precursor cell populations in the adult mouse brain. J Neurosci 16:2649-2658.

Dawson MR, JM Levine, Reynolds R (2000) NG2-expressing cells in the central nervous system: are they oligodendroglial progenitors? J Neurosci Res 61:471-479.

Dayer AG, Cleaver KM, Abouantoun T, Cameron HA (2005) New GABAergic interneurons in the adult neocortex and striatum are generated from different precursors. J Cell Biol 168:415-427.

Doetsch F, Caille I, Lim DA, Garcia-Verdugo JM, Alvarez-Buylla A (1999) Subventricular zone astrocytes are neural stem cells in the adult mammalian brain. Cell 97:703-716.

Doetsch F, Petreanu L, Caille I, Garcia-Verdugo, Alvarez-Buylla A (2002) EGF converts transit-amplifying neurogenic precursors in the adult brain into multipotent stem cells. Neuron 36:1021-1034.

Facchiano A, De Marchis F, Turchetti E, Facchiano F, Guglielmi M, Denaro A, Palumbo R, Scoccianti M, Capogrossi MC (2000) The chemotactic and mitogenic effects of platelet-derived growth factor-BB on rat aorta smooth muscle cells are inhibited by basic fibroblast growth factor. J Cell Sci 113:2855-2863.

Flames N, Long JE, Garratt AN, Fischer TM, Gassmann M, Birchmeier C, Lai C, Rubenstein JL, Marin O (2004) Short- and long-range attraction of cortical GABAergic interneurons by neuregulin-1. Neuron 44:251-261.

Fomchenko EI, Holland EC (2005) Stem cells and brain cancer. Exp Cell Res 306:323-329.

Fox IJ, Kornblum HI (2005) Developmental profile of ErbB receptors in murine central nervous system: implications for functional interactions. J Neurosci Res 79:584-597.

Fry DW, Bridges AJ, Denny WA, Doherty A, Greis KD, Hicks JL, Hook KE, Keller PR, Leopold WR, Loo JA, McNamara DJ, Nelson JM, Sherwood V,
Smaill JB, Trumpp-Kallmeyer S, Dobrusin EM (1998) Specific, irreversible inactivation of the epidermal growth factor receptor and erbB2, by a new class of tyrosine kinase inhibitor. Proc Natl Acad Sci USA 95:12022-12027.

Gage FH (2000) Mammalian neural stem cells. Science 287:1433-1438.

Gritti A, Frolichsthal-Schoeller P, Galli R, Parati EA, Cova L, Pagano SF, Bjornson CR, Vescovi AL (1999) Epidermal and fibroblast growth factors behave as mitogenic regulators for a single multipotent stem cell-like population from the subventricular region of the adult mouse forebrain. J Neurosci 19:3287-3297.

Hintermann E, Bilban M, Sharabi A, Quaranta V (2001) Inhibitory role of alpha 6 beta 4-associated erbB-2 and phosphoinositide 3-kinase in keratinocyte haptotactic migration dependent on alpha 3 beta 1 integrin. J Cell Biol 153:465-478.

Holland EC, Hively WP, DePinho RA, Varmus HE (1998) A constitutively active epidermal growth factor receptor cooperates with disruption of G1 cell cycle arrest pathways to induce glioma-like lesions in mice. Genes Dev 12:3675-3685.

Johnson FM, Saigal B, Donato NJ (2005) Induction of heparin-binding EGF-like growth factor and activation of EGF receptor in imatinib mesylate-treated squamous carcinoma cells. J Cell Physiol 205:218-227.

Junier MP (2000) What role(s) for TGFalpha in the central nervous system? Prog Neurobiol 62:443-473.

Kakita A, Goldman JE (1999) Patterns and dynamics of SVZ cell migration in the postnatal forebrain: monitoring living progenitors in slice preparations. Neuron 23:461-472.

Kakita A, Zerlin M, Takahashi H, Goldman JE (2003) Some glial progenitors in the neonatal subventricular zone migrate through the corpus callosum to the contralateral cerebral hemisphere. J Comp Neurol 458:381-388.

Kornblum HI, Hussain RJ, Bronstein JM, Gall CM, Lee DC, Seroogy KB (1997) Prenatal ontogeny of the epidermal growth factor receptor and its ligand, transforming growth factor alpha, in the rat brain. J Comp Neurol 380:243-261.

Kuhn HG, Winkler J, Kempermann G, Thal LJ, Gage FH (1997) Epidermal growth factor and fibroblast growth factor-2 have different effects on neural progenitors in the adult rat brain. J Neurosci 17:5820-5829.

Law AK, Pencea V, Buck CR, Luskin MB (1999) Neurogenesis and neuronal migration in the neonatal rat forebrain anterior subventricular zone do not require GFAP-positive astrocytes. Dev Biol 216:622-634.

LeVine SM, Goldman JE (1988) Embryonic divergence of oligodendrocyte and and astrocyte lineages in developing rat cerebrum. J Neurosci 8:3992-4006.

Libermann TA, Nusbaum HR, Razon N, Kris R Lax I, Soreq H, Wittle N, Waterfield MN, Ullrich A, Schlessinger J (1985) Amplification, enhanced expression and possible rearrangement of EGF receptor gene in primary human brain tumors of glial origin. Nature 313:144-147.

Lin ML, Bertics PJ (1995) Laminin responsiveness is associated with changes in fibroblast morphology, motility, and anchorage-independent growth: cell system for examining the interaction between laminin and EGF signaling pathways. J Cell Physiol 164:593-604.

Lindvall O, Kokaia Z, Martinez-Serrano A (2004) Stem cell therapy for human neurodegenerative disorders-how to make it work. Nat Med 10:S42-S50.

Ling BC, Wu J, Miller SJ, Monk KR, Shamekh R, Rizvi TA, Decourten-Myers G, Vogel KS, DeClue JE, Ratner N (2005) Role for the epidermal growth factor receptor in neurofibromatosis-related peripheral nerve tumorigenesis. Cancer Cell 7:65-75.

Marshall CA, Goldman JE (2002) Subpallial dlx2-expressing cells give rise to astrocytes and oligodendrocytes in the cerebral cortex and white matter. J Neurosci 22:9821-9830.

Moro L, Venturino M, Bozzo C, Silengo L, Altruda F, Beguinot L, Tarone G, Defilippi P (1998) Integrins induce activation of EGF receptor: role in MAP kinase induction and adhesion-dependent cell survival. EMBO 17:6622-6632.

Murase S, Horwitz AF (2002) Deleted in colorectal carcinoma and differentially expressed integrins mediate the directional migration of neural precursors in the rostral migratory stream. J Neurosci 22:3568-3579.

Nakatomi H, Kuriu T, Okabe S, Yamamoto S, Hatano O, Kawahara N, Tamura A, Kirino T, Nakafuku M (2002) Regeneration of hippocampal pyramidal neurons after ischemic brain injury by recruitment of endogenous neural progenitors. Cell 23:429-441. 
Nishikawa R, Ji XD, Harmon RC, Lazar CS, Gill GN, Cavenee WK, Huang HJ (1994) A mutant epidermal growth factor receptor common in human glioma confers enhanced tumorigenicity. Proc Natl Acad Sci USA 91:7727-7731.

Pencea V, Luskin MB (2003) Prenatal development of the rodent rostral migratory stream. J Comp Neurol 463:402-418.

Pozas E, Pascual M, Nguyewn Ba-Charvet KT, Guijarro P, Sotelo C, Chedotal A, Del Rio JA, Soriano E (2001) Age-dependent effects of secreted Semaphorins 3A, 3F, and 3E on developing hippocampal axons: in vitro effects and phenotype of semaphoring $3 \mathrm{~A}(-/-)$ mice. Mol Cell Neurosci 18:26-43.

Schmidt M, Reiser P, Hills D, Gullick WJ, Wels W (1998) Expression of an oncogenic mutant EGF receptor markedly increases the sensitivity of cells to an EGF-receptor-specific antibody-toxin. Int J Cancer 75:878-884.

Seroogy KB, Gall CM, Lee DC, Kornblum HI (1995) Proliferative zones of postnatal rat brain express epidermal growth factor receptor mRNA. Brain Res 23:157-164.

Smith JS, Tachibana I, Passe SM, Huntley BK, Borell TJ, Iturria N, O'Fallon JR, Schaefer PL, Scheithauer BW, James CD, Buckner JC, Jenkins RB (2001) PTEN mutation, EGFR amplification, and outcome in patients with anaplastic astrocytomas and glioblastoma multiforme. J Natl Cancer Inst 93:1246-1256.

Sun Y, Goderie SK, Temple S (2005) Asymetric distribution of EGFR receptor during mitosis generates diverse CNS progenitor cells. Neuron 45:873-886.

Suzuki SO, Goldman JE (2003) Multiple cell populations in the early postnatal subventricular zone take distinct migratory pathways: a dynamic study of glial and neuronal progenitor migration. J Neurosci 23:4240-4250.
Varley C, Hill G, Pellegrin S, Shaw NJ, Selby PJ, Trejdosiewicz LK, Southgate J (2005) Autocrine regulation of human urothelial cell proliferation and migration during regenerative responses in vitro. Exp Cell Res 306:216-229.

Weiss WA, Burns MJ, Hackett C, Aldape K, Hill JR, Kuriyama H, Kuriyama N, Milshteyn N, Roberts T, Wendland MF, DePinho R, Israel MA (2003) Genetic determinants of malignancy in a mouse model for oligodendrogliomas. Cancer Res 63:1589-1595.

Wong AJ, Ruppert JM, Bigner SH, Grzeschik CH, Humphrey PA, Bigner DS, Vogelstein B (1992) Structural alterations of the epidermal growth factor receptor gene in human gliomas. Proc Natl Acad Sci USA 89:2965-2969.

Xie H, Pallero MA, Gupta K, Chang P, Ware MF, Witke W, Kwiatkowski DJ, Lauffenburger DA, Murphy-Ullrich JE, Wells A (1998) EGF receptor regulation of cell motility: EGF induces disassembly of focal adhesions independently of the motility-associated PLCgamma signaling pathway. J Cell Sci 111:615-624.

Yarden Y, Sliwkowski MX (2001) Untangling the ErbB signalling network. Nat Rev Mol Cell Biol 2:127-137.

Yuan X, Chittajallu R, Belachew S, Anderson S, McBain CJ, Gallo V (2002) Expression of the green fluorescent protein in the oligodendrocyte lineage: a transgenic mouse for developmental and physiological studies. J Neurosci Res 70:529-545.

Zerlin M, Milosevic A, Goldman JE (2004) Glial progenitors of the neonatal subventricular zone differentiate asynchronously, leading to spatial dispersion of glial clones and to the persistence of immature glia in the adult mammalian CNS. Dev Biol 270:200-213. 